UNIVERSITÉ DU QUÉBEC

\author{
MÉMOIRE PRÉSENTÉ À \\ L'UNIVERSITÉ DU QUÉBEC À CHICOUTIMI \\ COMME EXIGENCE PARTIELLE
}

DE LA MAITTRISE EN RESSOURCES RENOUVELABLES

Par:

AZADEH EFTEKHARI

B.Sc. PATHOLOGIE VÉGÉTALE

\title{
CHEMICAL AND BIOLOGICAL STUDY ON CONSTITUENTS OF POPULUS TREMULOIDES BUDS
}

ÉTUDE CHIMIQUE ET ACTIVITÉS BIOLOGIQUES DES CONSTITUANTS DES BOURGEONS DU POPULUS

TREMULOIDES 


\section{Bibliothèque}

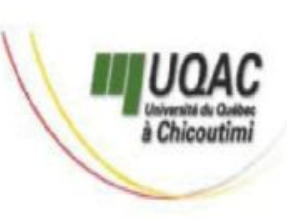

\section{Mise en garde/Advice}

Afin de rendre accessible au plus Motivated by a desire to make the grand nombre le résultat des results of its graduate students' travaux de recherche menés par ses research accessible to all, and in étudiants gradués et dans l'esprit des accordance with the rules règles qui régissent le dépôt et la governing the acceptation and diffusion des mémoires et thèses diffusion of dissertations and produits dans cette Institution, theses in this Institution, the I'Université du Québec à Université du Québec à Chicoutimi (UQAC) est fière de Chicoutimi (UQAC) is proud to rendre accessible une version make a complete version of this complète et gratuite de cette œuvre. work available at no cost to the reader.

L'auteur conserve néanmoins la The author retains ownership of the propriété du droit d'auteur qui copyright of this dissertation or protège ce mémoire ou cette thèse. thesis. Neither the dissertation or Ni le mémoire ou la thèse ni des thesis, nor substantial extracts from extraits substantiels de ceux-ci ne it, may be printed or otherwise peuvent être imprimés ou autrement reproduced without the author's reproduits sans son autorisation. permission. 


\section{ABSTRACT}

Nowadays, a large number of compounds derived from plants are used in modern medicine and a majority of them are inspired by traditional applications. About $60 \%$ of anticancer drugs and $75 \%$ of compounds for infectious diseases are either natural products or their derivatives. However, it is estimated that only bioactive molecules of 5 to $15 \%$ of more than 250'000 plants species on earth have been investigated. Particularly, few scientific studies have been conducted on bioactive compounds from the medicinal plants of the boreal forest, wide-spread in Quebec and Canada. In recent years, LASEVE laboratory has evaluated the potential pharmacology of many plants and it was apparent that the buds of Populus tremuloides would represent an interesting subject of study in chemistry and pharmacology. In North America, leaf-buds of $P$. tremuloides were used in traditional medicine to treat numerous diseases. The aim of this research project was to isolate and characterize the polyphenolic constituents in buds of $P$. tremuloides and to evaluate the biological activities of the purified fractions and pure compounds. Phytochemical investigations of the EtOH extract of $P$. tremuloides leaf-buds led to the isolation of 24 phenolic compounds. Among them, one compound is a new molecule and was not reported in literature before; two compounds were not reported before for Salicaceae family; two compounds were not reported before for Populus genus; and ten compounds were identified for the first time in $P$. tremuloides. Three of the identified compounds have exhibited a moderate to strong cytotoxicity $(5-20 \mu \mathrm{M})$ towards some of cellular tested lines (WS1, DLD-1, A-549). Anti-inflammatory activity of five phenolic compounds having a glycerol section has been evaluated using LPS-stimulated RAW 264.7 macrophages. Only one of the tested compounds significantly inhibited nitric oxide production $\left(\mathrm{IC}_{50}: 6.5 \pm 0.4 \mu \mathrm{M}\right.$ ), without cytotoxicity. Finally, none of the phenolic compounds isolated in the present work have exhibited a significant activity against Staphylococcus aureus and Escherichia coli. 


\section{RÉSUMÉ}

De nos jours, un grand nombre de composés d'origine végétale sont utilisés dans la médecine moderne. Plusieurs d'entre eux ont été développés en s'inspirant des informations de la médecine traditionnelle. Environ $60 \%$ des anticancéreux et $75 \%$ des antimicrobiens de l'arsenal thérapeutique actuel sont des produits naturels ou des dérivés. Seulement $5-15 \%$ des 250000 plantes ont été étudiées afin d'en évaluer le potentiel pharmacologique. Les plantes de la forêt boréale québécoise ont été très peu étudiées au niveau de leur composition chimique et de leur potentiel pharmacologique. Au cours des dernières années, le laboratoire LASEVE a évalué le potentiel pharmacologique de plusieurs plantes et il en est ressorti que les bourgeons du Populus tremuloides représentaient un sujet d'étude intéressant au niveau chimique et pharmacologique. De plus, cette espèce a été utilisée en médecine traditionnelle pour traiter de nombreuses maladies. L'objectif de ce projet était d'isoler et de caractériser les composés phénoliques majoritaires des bourgeons de Populus tremuloides et d'en évaluer l'activité biologique (anticancéreuse, anti-inflammatoire et antibactérienne). Les travaux effectués sur l'extrait éthanolique des bourgeons de Populus tremuloides ont mené à l'identification de 24 composés phénoliques. Un de ces composés n'a jamais été rapporté auparavant dans la littérature scientifique et deux autres n'ont jamais été signalés dans la famille des Salicacées. De plus, dix de ces composés sont identifiés pour la première fois dans le Populus tremuloides. Trois des composés identifiés ont démontré une cytotoxicité de forte à modérée (5-20 $\mu \mathrm{M}$ ) envers certaines des lignées cellulaires testées (WS1, DLD-1, A-549). L'activité anti-inflammatoire de cinq composés phénoliques constitués d'une section glycérol a été évaluée sur des macrophages de souris RAW 264.7 stimulé avec le LPS (lipopolysaccharide). Un seul des composés testés a significativement inhibé, sans cytotoxicité, la production d'oxyde nitrique avec une $\mathrm{IC}_{50}$ de $6.5 \pm 0.4 \mu \mathrm{M}$. Finalement, aucun des composés phénoliques isolés dans ces travaux n'a démontré une activité importante contre Staphylococcus aureus et Escherichia coli. 


\section{ACKNOWLEDGMENTS}

At first, I would like to express my gratitude to the director of my program, Professor André Pichette, for his patience and gentle supervision. It was great to have the privilege to work with him and to learn from his expertise in the past two years. Special thanks to my co-director, Professor Jean Legault, for his support and guidance. I am very grateful for all of his time and attention during this research.

Special thanks to Dr. Vakhtang Mshvildadze and Mr. Serge Lavoie, for their kind help throughout this study and to my colleagues with whom I shared these years of research in LASEVE laboratory.

I am pleased to have participated in the master program offered by the Universite du Québec à Chicoutimi, where I had the chance to develop my skills and find forwardlooking friends.

Last, but not least, I am also most grateful to my husband, Alireza, for his never-ending support and understanding in all the situations and to my parents for unconditional support and encouragement. 


\section{TABLE OF CONTENTS}

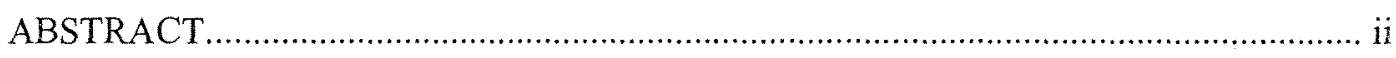

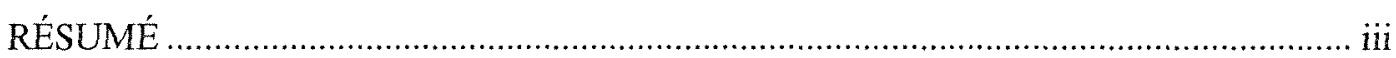

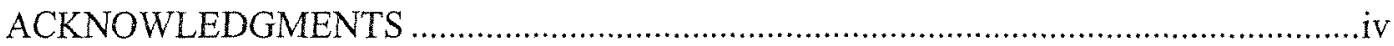

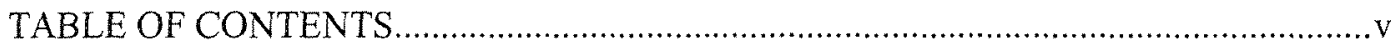

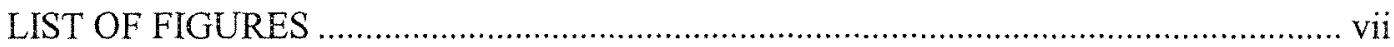

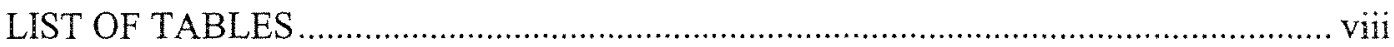

I. INTRODUCTION

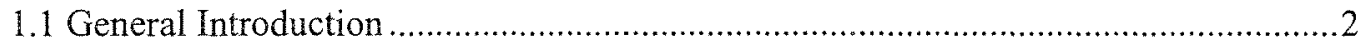

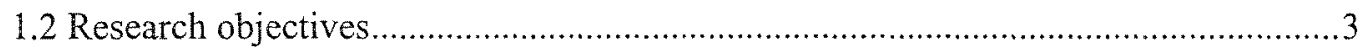

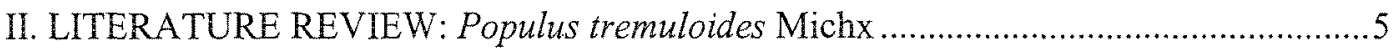

2.1 Principle Characteristics of Populus tremuloides .........................................................6

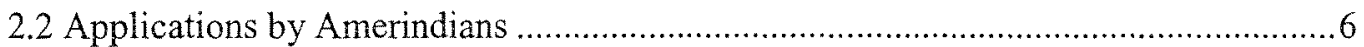

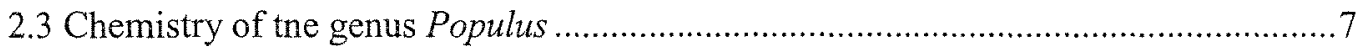

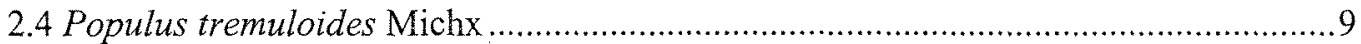

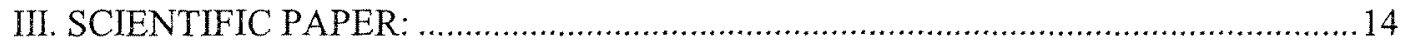

Cytotoxic phenolic compounds in leaf-buds of Populus tremuloides ............................14

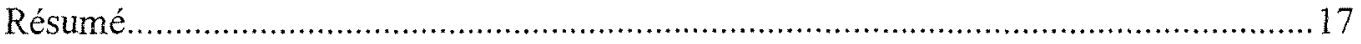

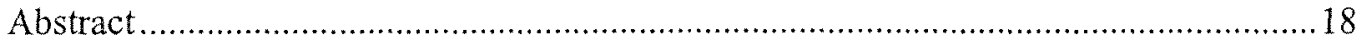

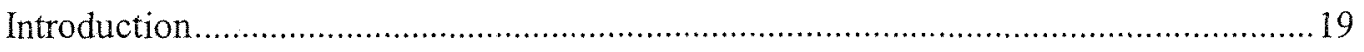

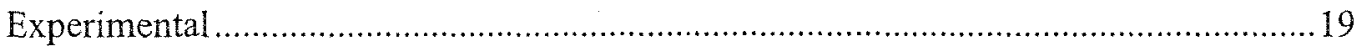

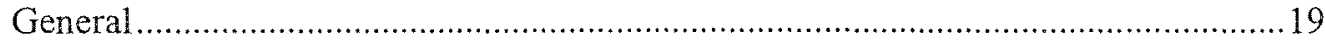

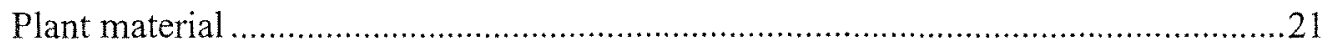

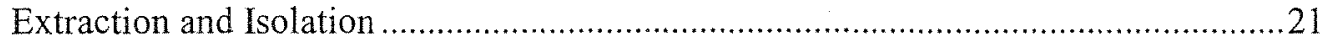

$(1 S, 2 S)-1-[4-\mathrm{O}-E$-coumaroyl- $\beta$-D-glucopyranosyloxy]cyclohexanediol $(1) \ldots \ldots \ldots \ldots . . .23$

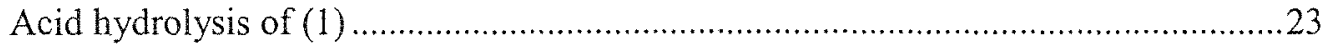

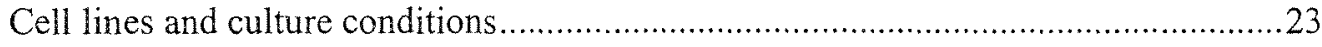

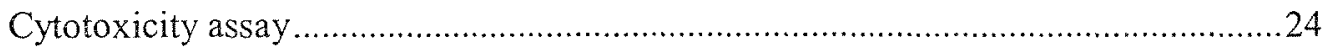




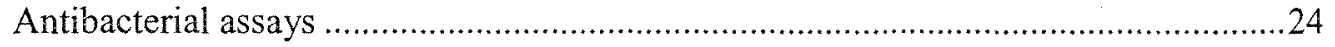

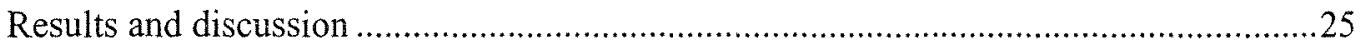

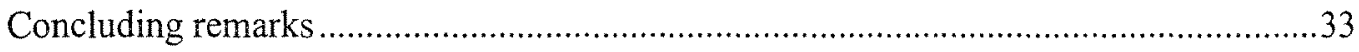

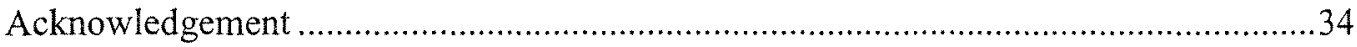

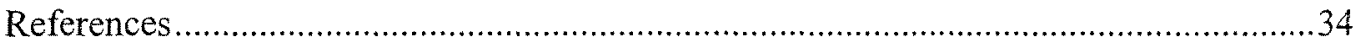

IV. RESULTS AND DISSCUSSTION: Other results related to phytochemical study of

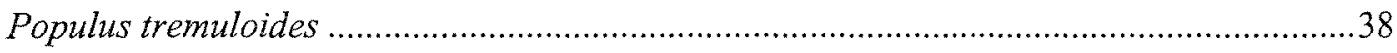

4.1 Isolation and purification of phenolic compounds ....................................................39

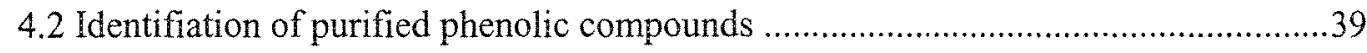

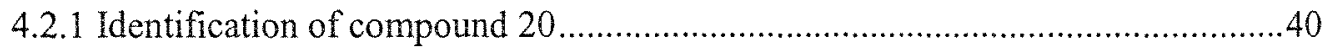

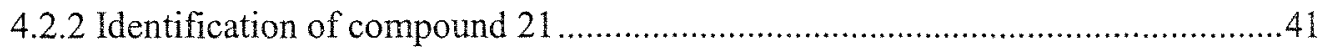

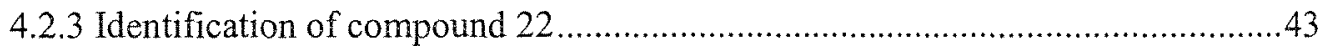

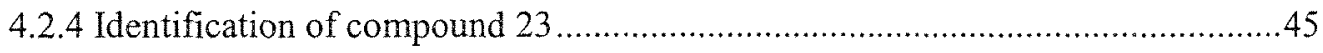

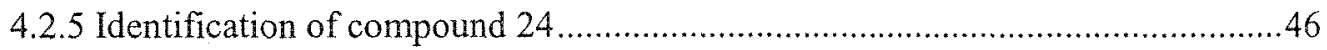

4.3 Evaluation of cytotoxicity against human cell lines ..............................................48

4.4 Evaluation of the anti-inflammatory activity of isolated compounds on LPS activated

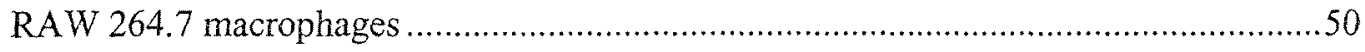

4.5 Evaluation of antibacterial activity of compounds isolated from Populus tremuloides.

V. CONCLUDING REMARKS AND FUTURE DIRECTIONS ..................................54

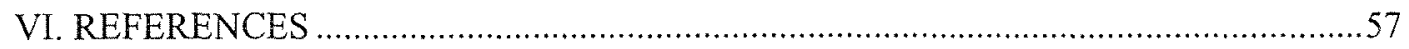

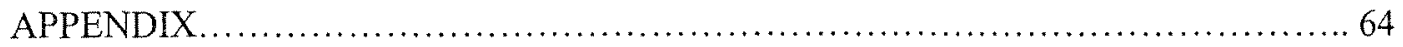




\section{LIST OF FIGURES}

Figure 1: (a) Distribution of $P$. tremuloides in North America, (b) trees of P.tremuloides,

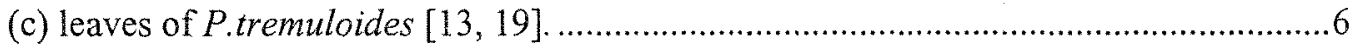

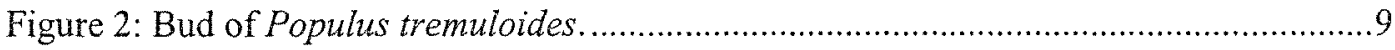

Figure 3: Molecular structure of some compounds described by Fernandez et al [50].......10

Figure 4: Triterpenes constituents from the heartwood of $P$. tremuloides $[51] \ldots \ldots \ldots \ldots \ldots \ldots . .12$

Figure 5: Five phenolic compounds from buds of $P$. tremuloides .....................................40

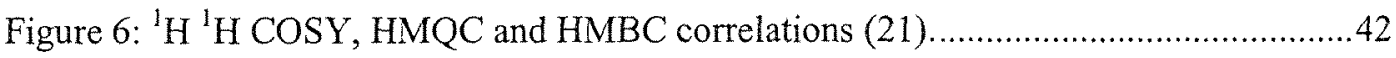

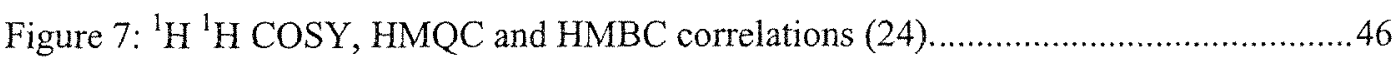




\section{LIST OF TABLES}

Table 1: GC-MS identification of the $P$. tremuloides pulp and paper constituents [1] ......11

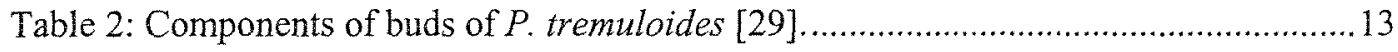

Table 3: ${ }^{1} \mathrm{H}$ and ${ }^{13} \mathrm{C}$ NMR spectroscopic data for compound 20 in methanol-d4. ...............41

Table 4: ${ }^{1} \mathrm{H}$ and ${ }^{13} \mathrm{C}$ NMR spectroscopic data for compound 21 in methanol-d4 ..............42

Table 5: ${ }^{1} \mathrm{H}$ and ${ }^{13} \mathrm{C}$ NMR spectroscopic data for compound 22 in methanol-d4, ...............44

Table $6:{ }^{1} \mathrm{H}$ and ${ }^{13} \mathrm{C}$ NMR spectroscopic data for compound 23 in methanol-d4, .............45

Table 7: ${ }^{1} \mathrm{H}$ and ${ }^{13} \mathrm{C}$ NMR spectroscopic data for compound 24 in methanol-d4, .............47

Table 8: In vitro cytotoxicity results of phenolic compounds. .........................................49

Table 9: NO Inhibition induced by phenolic compounds on LPS-activated RAW 264.7

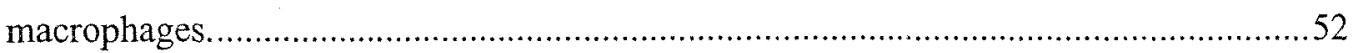

Table 10: Antibacterial activity of phenolic compounds against $S$. aureus and E. coli......53 
Chapter I

INTRODUCTION 


\subsection{General Introduction}

The use of plants as medicines has a long history. Written proofs of man's ingenuity in using plants for treatment of various diseases are present by ancient Chinese, Indians, and North Africans [1]. These plants were initially used without modification, then as concentrated extracts to increase their effectiveness or as dried form to keep them for longer times with less degradation. In the $1900 \mathrm{~s}$, people learned how to isolate active compounds from medicinal plants.

Even today, natural products are important sources of drugs and almost $60 \%$ to $75 \%$ of the world's population use plant-based medicines for initial pharmaceutical cure [2]. Between 1981 and 2002, it is estimated that almost $50 \%$ of new chemical entities authorized to initiate clinical studies were natural products or related natural products [3]. Moreover, natural products exhibiting various biological activities usually possess a complex and diverse structure leading to strong challenges in organic synthesis $[3,4]$. About $60 \%$ of anticancer drugs and $75 \%$ of compounds for infectious diseases are either natural products or their derivatives $[5,6]$. It is commonly accepted that less than $15 \%$ of the plants were studied regarding their biological activities $[7,8]$.

In Canada, one of the most important natural resources is the boreal forest. The latter plays an important role in the traditional medicine of Canadian First Nations communities [9]. However, real effectiveness of these potential drugs is rarely studied in scientific ways. Few biopharmaceutical studies were undertaken on plant species of the boreal forest of Canada $[9,10]$. Based on the knowledge acquired by First Nations communities, LASEVE 
laboratory reported the identification of an antitumoral compounds from balsam fir [11]. Following this result, a large effort of this laboratory has been devoted to research on potential pharmaceutical contents in biomass of the boreal forest.

This project is inspired by previous research work performed on other Populus species (Populus balsamifera). The present research is focused on chemical and biological properties of bud constituents of the most widely distributed species of Populus in boreal forest, named Populus tremuloides.

\subsection{Research objectives}

The main goals of this research project are:

- Isolation and characterization of polyphenolic constituents from the buds of $P$. tremuloides.

- Investigation of crude extract, purified fractions and pure compounds for antibacterial, anti-inflammatory and cytotoxic activities (in vitro).

- Identification of the active compound(s) through bioassay-guided fractionation.

- Study of the relationship between the chemical structures and the biological activities.

This thesis is divided into five chapters. The first chapter is dedicated to the thesis outlines. Chapter II covers literature reviews about botany, applications and phytochemistry of the genus Populus and the species of Populus tremuloides. Chapter III presents a 
scientific paper dealing with Cytotoxic polyphenols in leaf-buds of $P$. tremuloides. This article was accepted in Canadian Journal of Chemistry. Chapter IV describes the scientific work related to anti-inflammatory phenolic compounds from buds of Populus tremuloides and finally in Chapter $\mathrm{V}$, conclusions and future directions are covered. 
Chapter II

LITERATURE REVIEW: Populus tremuloides Michx 


\subsection{Principle Characteristics of Populus tremuloides}

Populus tremuloides (Quaking aspen), from Salicaceae family is a decidous tree native to cooler areas of North America. It is a tall tree, usually 20 to 25 meters high at maturity, with a trunk diameter comprised between 20 to $80 \mathrm{~cm}[12,13]$. As shown in figure 1, this tree has a geographical distribution from Alaska to the east coast of Canada and is present down south in scattered populations (New Mexico state). However, It is absent from the central and south-eastern plains. It grows in humid calcium-rich soils.

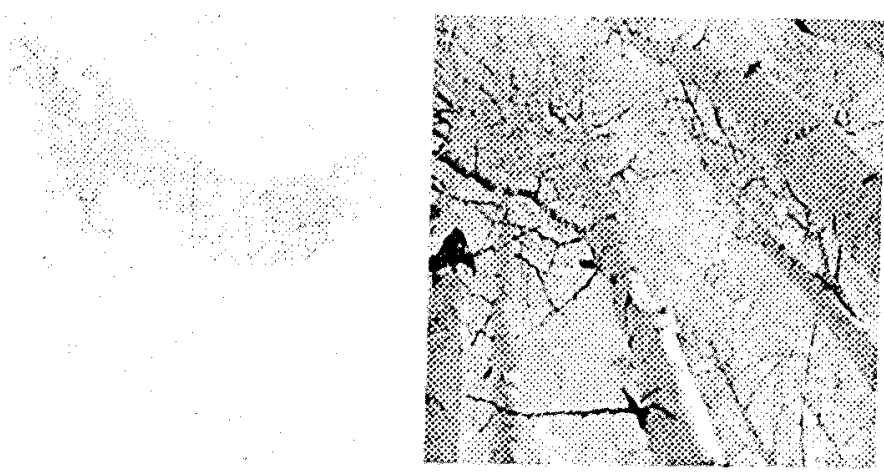

(a) (b)

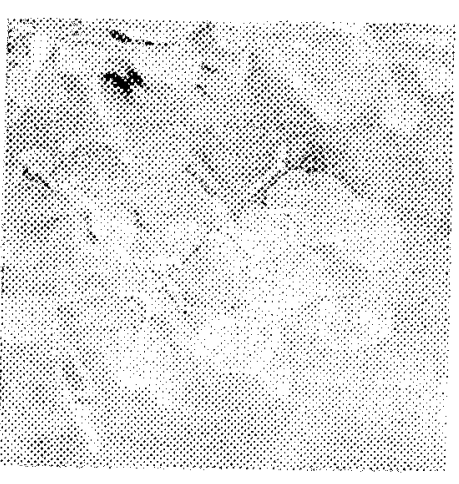

(c)

Figure 1: (a) Distribution of P. tremuloides in North America, (b) trees of P.tremuloides, (c) leaves of P.tremuloides $[13,19]$.

\subsection{Applications by Amerindians}

Quaking aspen has been used as herbal medicine for centuries. First Nations communities widely used this species especially for its antiseptic and analgesic properties for wounds healing and against skin complaints and disorders [9]. Now, it has similar applications in modern herbalism. 
Its bark had applications in the treatment of rheumatism, arthritis, gout, lower back pains, urinary complaints, digestive and liver disorders, debility, and anorexia [14-16]. It also could reduce fevers and relieve the pain of menstrual cramps [16]. Infusion of inner bark was a remedy for coughs as well as a treatment for stomach pains, colds and fever [16$17]$.

Leaf-buds had applications as a nasal salve for children and adults to fight coughs, colds and irritated nostrils $[9,18]$. They were also used against chronic bronchitis and rheumatism and externally for treating superficial wounds, external haemorrhoids, frostbite, sunburn and as an ointment for myalgia [19].

\subsection{Chemistry of tne genus Populus}

Having fast growth rates, the genus Populus attracted many economical interests, such as in the wood pulp industry and motivated longstanding investigations about its chemistry [20]. The genus tree family contains phenolic glycosides which are important secondary metabolites regarding plant resistance to both insect and mammalian herbivores [21, 22]. Finally, chemical principles from Populus species are known to have various biological activities such as fungicidal, antioxidant, antitumor, antiseptic and antiviral properties [2325].

Several classes of natural products such as polyphenols, terpenoids, fatty acids, aliphatic alcohols and hydrocarbons are found in the genus Populus [26-29]. Due to difficulty in identification of Salicaceae species only based on morphological identification, secondary 
phenolics were used as chemotaxonomic purposes. The chemotaxonomy of poplar (Populus spp) is related to a complex mixture of compounds in their bud exudates which include benzoic and phenolic acids and their esters, flavanoid aglycones, hydrocarbons and terpenoids $[30,31]$. The presence of some phenolic compounds can be used as a 'fingerprint' to identify poplar species [32] since many phenolic components of buds exudates of European, Asian, and North American poplar species have been studied in recent years [33-38]. The analysis of poplar bud exudates have shown a high degree of complexity. The typical poplars of a particular section have a bud exudate composition which is characteristic of that section. For example, section Leuce, subsection Albidae, e.g P. alba L., exude only hydrocarbons [39] whereas those of subsection Trepidae, e.g. $P$. tremuloides Michx., secrete a phenolic exudate which includes only the flavanones produced by the first steps of flavonoid metabolism, such as naringenin $\left(S, 7,4^{\prime}-\right.$ trihydroxyflavonone) and its methyl ethers [29]. By contrast poplars of section Aigeiros, such as P.deltoides Marsh [40] and P.nigra L. [41], and of section Tacamahacha, such as P.balsamifera L. [42], produce a more complex bud exudate, which contains primarily flavonoids resulting from the further metabolism of naringenin. Phenolic compounds are also exuded onto the leaf surfaces of some poplars, such as $P$. deltoides [43] and $P$. nigra [44]. The bud of $P$. tremuloides is shown in figure 2.

Propolis, a resinous hive product collected by honeybees from parts of plants, especially buds and exudates of Populus species, has been used as folk medicines about 300 years before Christ (BC). Different biological activities, such as anticancer, antioxidant, antiinflammatory, antibiotic and antifungal effects have been reported for propolis and its 
constituents. It has also been extensively used in food and beverages to improve health and prevent diseases such as inflammation, heart disease, diabetes and even cancer. Recently there is a renewed interest in the composition of propolis and related poplars [45-48]. Recently, it has been proven that the phenolic content of northern propolis is mainly inherited from Populus spp., a very attractive tree for honey bees of Canada. Thus, considering the promising biologically-active substances in propolis inheritated from poplars of section Leuce, subsection Trepidae, its plant source which is $P$. tremuloides is worth further investigation [49].

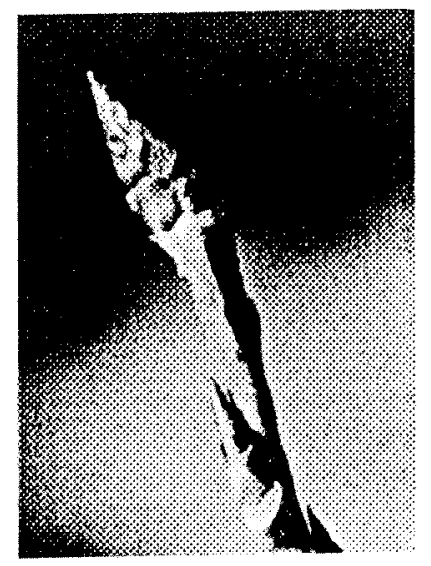

Figure 2: Bud of Populus tremuloides.

\subsection{Populus tremuloides Michx}

While $P$. tremuloides has a rather prominent importance as a model system for ecological and environmental research by the forest industries, few phytochemical or pharmacological studies were conducted so far on $P$. tremuloides. Fernandez et al. has identify 44 compounds (12 of them are shown in figure 3) such as phenolic compounds, 
fatty acids, steroids, triterpenes and lipids in processing of $P$. tremuloides Michx. for pulp and paper, with a rapid gas chromatography-mass spectrometry (GC-MS) method, summarized in table $1[50]$.

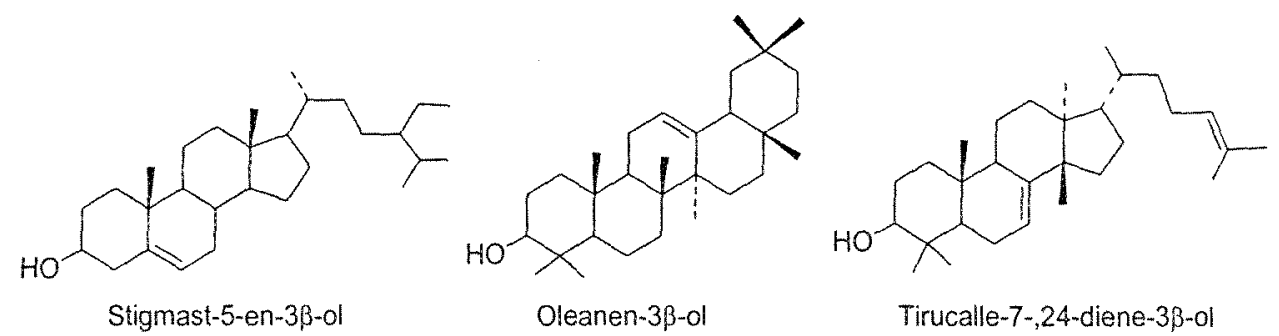<smiles>CC(C)=CCCC(C)C1CCC2C3CCC4C(CCC(O)C4(C)C)C3CCC12C</smiles>

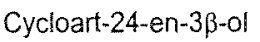<smiles>CC1CCC2(C)CCC3(C)C(CCC4C3CCC3C(C)(C)C(O)CCC43C)C2C1C</smiles>

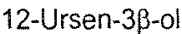<smiles>C=C(CCC(C)C1CCC2(C)C3CCC4C(C)(C)C(O)CCC4(C)C3CCC12C)C(C)C</smiles>

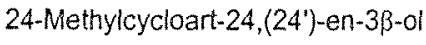<smiles>C/C=C(\CC)CCC1CCC2C3=CCC4C(C)C(O)CCC4(C)C3CCC12C</smiles>

Citrostadienol<smiles>[R]C1CCC2(C)C3CCC4C5C(C(=C)C)CCC5(C)CCC4(C)C3CCC2C1(C)C</smiles>
20(29)-Lupen-3ß-yIR<smiles>CCCCC(C)CCCC(C)CCCC1(C)CCc2c(C)c(O)c(C)c(C)c2O1</smiles>
$\alpha$-Tocopherol<smiles>COc1cc(O)c2c(c1)OC(c1ccc(O)cc1)CC2=O</smiles>

5,4'-Dihydroxy-7methoxyflavanone<smiles>O=C(O)C=Cc1ccc(O)cc1</smiles>

3-(4-Hydroxypheny))-2-propenoic acid

Hexadecanoic acid

Figure 3: Molecular structure of some compounds described by Fernandez et al [50]. 
Table 1: GC-MS identification of the P. tremuloides pulp and paper constituents [1].

\begin{tabular}{|c|c|}
\hline Compound family & Name of compounds \\
\hline \multirow{13}{*}{ Monoaryl phenolics } & benzoic acid \\
\hline & 1-Ethyl-4-hydroxybenzene \\
\hline & 3-(2-Hydroxyphenyl)-2-propenoic acid \\
\hline & 2-hydroxybenzyl alcohol \\
\hline & 4-Hydroxy-2-methylacetophenone \\
\hline & 4-Hydroxybenzoic acid \\
\hline & 3*(4-Hydroxyphenyl) propanoic acid \\
\hline & 3-(4-Hydroxy-3-methoxyphenyl)-2-propen-1-ol \\
\hline & 3-(4-Hydroxy-3-methoxyphenyl)-2-propenal \\
\hline & 3-(4-Hydroxyphenyl)-2-propenoic acid \\
\hline & 4-(4-Hydroxy-3-methoxypheny1)-2-propenoic acid \\
\hline & 4-(3-Hydroxy-1-propenyl)-2,6-dimethoxyphenol \\
\hline & 3-(4-Hydroxy-3,5-dimethoxypheny1)-2-propen-1al \\
\hline \multirow{8}{*}{ Fatty acids } & 9-oxononanoic acid \\
\hline & Hexadecanoic acid \\
\hline & $(\mathrm{Z}, \mathrm{Z})-9,12$-Octadecadienoic acid \\
\hline & Octadecadienoic acid \\
\hline & Eicosanoic acid \\
\hline & Docosanoic acid \\
\hline & Tetracosanoic acid \\
\hline & 1-Docosanol \\
\hline \multirow{4}{*}{ Flavonoids } & 4,5-Dihydroxy-7-methoxyflavanone \\
\hline & 4',5,7-Trihydroxyflavanone \\
\hline & 3,5,7-Trihydroxy-4'-methoxyflavone \\
\hline & 3,4',5,7-Tetrahydroxyflavone \\
\hline \multirow{7}{*}{ Sterols / triterpene alcohols } & Stigmast-5-en-3ß-ol \\
\hline & 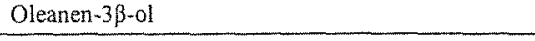 \\
\hline & 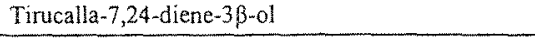 \\
\hline & Cycloart-24-en-3ß-ol \\
\hline & 12-Ursen- $3 \beta$-ol \\
\hline & 24-Methylcycloart-24,(24)-en-3B-ol \\
\hline & Citrostadeniol \\
\hline \multirow{10}{*}{ Steryl/ triterpene esters } & 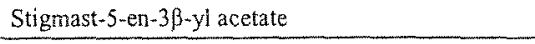 \\
\hline & Tirucalla-7,24-diene-3 3 -yl hexadecanoate \\
\hline & 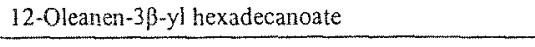 \\
\hline & 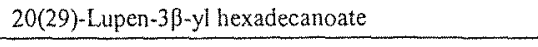 \\
\hline & 12-Ursen-3 3 -yl hexadecanoate \\
\hline & 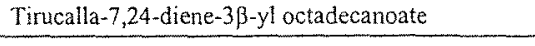 \\
\hline & 12-Oleanen-3 3 -yl octadecanoate \\
\hline & 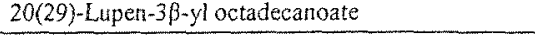 \\
\hline & 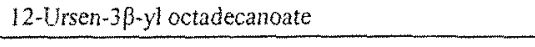 \\
\hline & 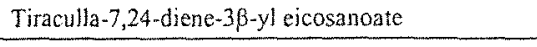 \\
\hline \multirow{2}{*}{ Lipids } & $a$-tocophérol \\
\hline & (9Z.12Z)-Glycerol tri-9,12-octadecadienoate \\
\hline
\end{tabular}


The extractives of unsaturated alcohol fraction from $P$. tremuloides heartwood have been studied by Abramovitich and Micetich [51] and their work resulted in the identification of triterpenes and sterols, as shown in figure 4.
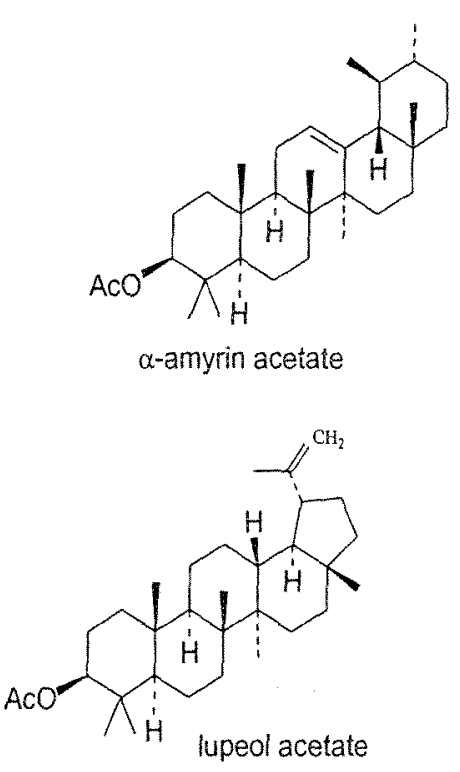
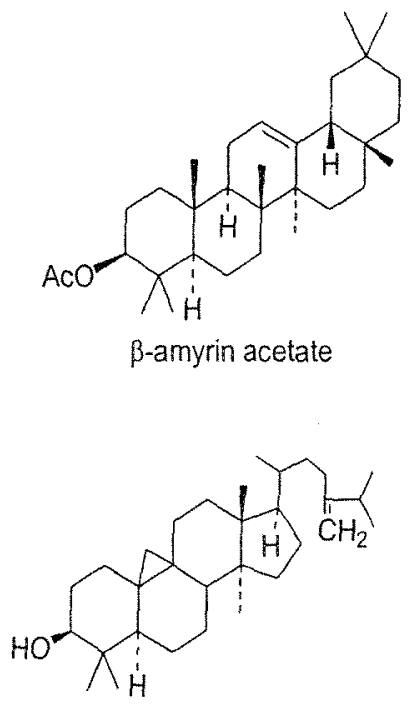

24-methylenecycloartanol
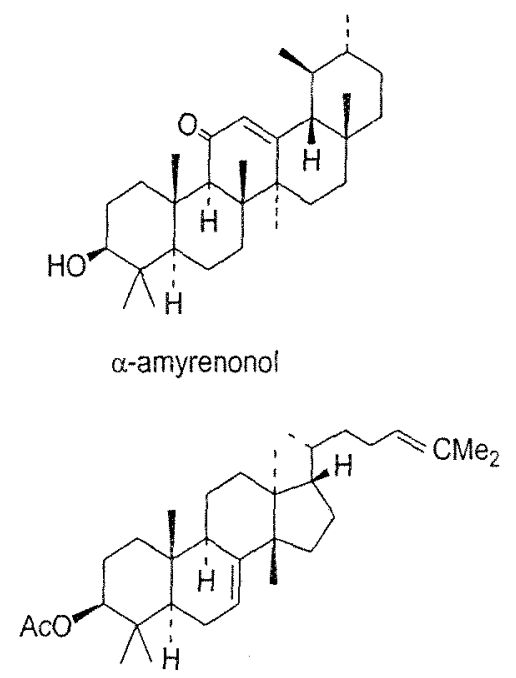

butyrospermol acetate

Figure 4: Triterpenes constituents from the heartwood of $P$. tremuloides [51].

Pearl et al. [52] showed that leaves of P. tremuloides provide a good source of the 6monobenzoate of salicin, populin, while the bark of the same species provides a good source of the 2-monobenzoate of salicin, tremuloidin [52, 53]. Lindroth et al. [54] identified phenolic glycosides components, such as salicin, salicortin, tremuloidin, tremulacin from the crude extract of $P$. tremuloides leaves which exhibited differential toxicity against the insects such as Papilio glaucus subspecies. 
Phytochemical investigation by English et al. [29] with GC-MS on buds of $P$. tremuloides revealed phenolic compounds, flavonoids and hydrocarbons listed in table 2.

Table 2: Components of buds of $P$. tremuloides [29].

\begin{tabular}{|c|c|}
\hline Compound family & Name of compounds \\
\hline \multirow{9}{*}{ Phenolic compounds } & Benzyl benzoate \\
\hline & $p$-Coumaric acid \\
\hline & Ferulyl alcohol \\
\hline & Ferulic acid \\
\hline & Caffeic acid \\
\hline & Benzyl p-coumarate \\
\hline & Ferulyl benzoate \\
\hline & Benzyl ferulate \\
\hline & Benzyl caffeate \\
\hline \multirow{5}{*}{ Flavonoides } & Isosakuranetin \\
\hline & Isosakuranetin chalcone \\
\hline & Sakuranetin \\
\hline & Sakuranetin chalcone \\
\hline & Kaempferol methyl ether \\
\hline \multirow{4}{*}{$\begin{array}{l}\text { Hydrocarbones } \\
\text { (straight chain) }\end{array}$} & Tricosane \\
\hline & Pentacosane \\
\hline & Heptacosane \\
\hline & Nonacosane \\
\hline Hydrocarbon alcohol & 1-Hexacosanol \\
\hline
\end{tabular}


Chapter III

\section{SCIENTIFIC PAPER:}

\section{Cytotoxic phenolic compounds in leaf-buds of}

\section{Populus tremuloides.}

Accepted in Canadian Journal of Chemistry (2009-10-05) 


\section{Graphical abstract}

Bioassay-guided fractionation and separation of the EtOH extract of Populus tremuloides leaf-buds resulted in the isolation of a new compound, $(1 S, 2 S)-1-[4-O-(E)-$ coumaroyl- $\beta$-D-glucopyranosyloxy]cyclohexane-diol 1 , and 18 known products. In vitro cytotoxic and antibiotic activities were evaluated for 18 of them.<smiles>O=C(/C=C/c1ccc(O)cc1)O[C@H]1C(CO)O[C@@H](O[C@@H]2CCCC[C@H]2O)[C@H](O)[C@H]1O</smiles> 


\section{Cytotoxic phenolic compounds in leaf-buds of Populus tremuloides.}

André Pichette*, Azadeh Eftekhari, Patricia Georges, Serge Lavoie, Vakhtang Mshvildadze and Jean Legault.

Chaire de recherche sur les agents anticancéreux d'origine naturelle, Département des sciences fondamentales, Université du Québec à Chicoutimi, Québec, Canada, G7H 2B1.

\section{* Corresponding author}

Université du Québec à Chicoutimi

Département des sciences fondamentales

Laboratoire LASEVE

555 , boulevard de l'Université

Chicoutimi, Québec, Canada

G7H 2B1

Phone: +1 (418) 545-5011 ext. 5081

Fax: +1 (418) 545-5012

e-mail: andre pichenerougeca 


\section{Résumé}

Les enquêtes phytochimique menés sur l'extrait éthanolique des feuilles-bourgeons du P. tremuloides ont conduit à l'isolement de 19 composés phénolique. Parmi eux, on y trouve est une nouvelle molécule, (1S, 2S) -1 - [4-O-E-coumaroyl $\beta$-D-glucopyranosyloxy] cyclohexanediol. La structure de cette dernière a été déterminée par spectroscopie (RMN et MS) et par des méthodes chimiques. Les autres Dix-huit composés isolés ont été testés pour l'activité cytotoxique en comparaison avec celle des lignées cancéreuses des poumons (A549) et celle du côlon (DLD-1) présent dans les cellules humaines affectés. L'activité antibactérienne a également été évaluée contre l'Escherichia coli et le Staphylococcus aureus. 


\begin{abstract}
Phytochemical investigations of the EtOH extract of Populus tremuloides leaf-buds led to the isolation of 19 phenolic compounds. Among them, $(1 S, 2 S)-1-[4-\mathrm{O}-E$-coumaroyl- $\beta$ D-glucopyranosyloxy]cyclohexanediol was reported for the first time and its structure was determined by spectroscopic (NMR and MS) and chemical methods. Seventeen of isolated compounds were tested for their cytotoxicity against lung carcinoma (A549) and colorectal adenocarcinoma (DLD-1) human cell lines. Antibacterial activity was also evaluated against Escherichia coli and Staphylococcus aureus.
\end{abstract}

Keywords

Quaking aspen; coumarate; flavonoids; NMR. 


\section{Introduction}

The buds exudates of many plant species of Populus genus are known as raw material processed by bees into propolis (1). The latter product has been widely used in popular medicine as antibacterial (2-4), anti-inflammatory (5), antioxidant (6-7) and cytostatic treatments (8). The biological activity of propolis samples is mainly due to phenolic compounds like flavonoids, aromatic acids and diterpenic acids (9-10) which are the principal constituents of the buds of Populus species (11-13). Recently, studies in the northern-type propolis showed a potential source of biologically-active substances in $P$. tremuloides (14) which are widely spread across North America (15). In spite of its use as ointment by Amerindian traditional medicine to treat numerous diseases such as coughs, colds and irritated nostrils (16), few studies were carried out on the medicinal applications. In the present study, the isolation and structure elucidation of a new phenolic compound from Populus tremuloides Michaux, along with 18 known products are described.

\section{Experimental}

\section{General}

Optical rotations were measured with an automatic polarimeter Rudolph Research Analytical Autopol IV. FTIR spectra were recorded with a Perkin-Elmer SpectrumOne. High resolution electrospray ionization mass spectrum was conducted in positive mode with an Applied Biosystems/MDS Sciex QSTARXL QqTOF MS system. The 1D and 2D NMR spectra ( ${ }^{1} \mathrm{H}^{\prime}{ }^{\prime} \mathrm{H}$ COSY, HSQC and HMBC) were performed using an Avance 400 
Bruker spectrometer equipped with a $5 \mathrm{~mm}$ QNP-probe. Chemical shifts were expressed in $\delta(\mathrm{ppm})$ units relative to TMS as an internal standard and coupling constants were given in Hertz. Preparative HPLC was performed on an Agilent 1100 liquid chromatography system, equipped with a solvent delivery system, an autosampler and a UV-MWD detector. Samples were eluted in an Intertsil prep-ODS column $\mathrm{C} 18(20 \times 250 \mathrm{~mm} ; 10 \mu \mathrm{m})$ at room

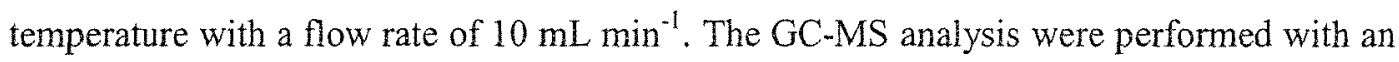
instrument (Agilent Technologies 6890N) fitted with a mass selective detector (Agilent Technologies 5973), a split-splitless injection port and an apolar capillary column DB-5MS $(30 \mathrm{~m} \times 0.25 \mathrm{~mm} \times 0.25 \mu \mathrm{m})$.

Analytical thin-layer chromatography was performed with silica gel $60 \mathrm{~F}_{254}, 0.25 \mathrm{~mm}$ pre-coated TLC plates (Silicycle, Québec, Canada). Flash column chromatographies were performed on silica gel (40-63 $\mu \mathrm{m}$ with indicator $F_{254}$, Silicycle, Québec, Canada) and on $\mathrm{C}_{18}$ reversed phase silica gel (carbon $11 \%, 40-69 \mu \mathrm{m}$, Silicycle, Québec, Canada). Polyamide CC-6 was purchased from Macherey-Nagel (Germany) and Diaion HP-20 from Supelco. Detection of the phenolic compounds was carried out by spraying TLC plates with polyethylene glycol (NP/PEG) reagent followed by heating at $110^{\circ} \mathrm{C}$ and detected by UV absorption at 254 and $365 \mathrm{~nm}$. TLC identification of monosaccharides were performed with $\mathrm{CH}_{2} \mathrm{Cl}_{2}-\mathrm{MeOH}-\mathrm{H}_{2} \mathrm{O}(50: 25: 5)$ solvent system. The compounds were visualized by spraying an orthophosphoric acid solution of naphtoresorcinol $5 \%$ in EtOH, followed by heating at $110^{\circ} \mathrm{C}$. 
The commercial samples used for biological tests, namely prunin (3), kaempferide (13) and trans-ferulic acid (19), were purchased from Indofine Chemical Company (USA). Rhamnocitrin (10) was purchased from Apin Chemicals Ltd (UK).

\section{Plant material}

Leaf-buds of Populus tremuloides Michaux were collected in the boreal forest to the south of Chicoutimi, Québec, Canada, in April 2006. Samples were identified by Patrick Nadeau (Département des sciences fondamentales, Université du Québec à Chicoutimi). A voucher specimen (QFA-A540466) was deposited at the Herbarium Louis-Marie of Université Laval, Québec, Canada.

\section{Extraction and Isolation}

The buds of Populus tremuloides $(1 \mathrm{~kg})$ were exhaustively extracted with EtOH $(3 \mathrm{~L}, 60$ ${ }^{\circ} \mathrm{C}, 3$ times, $2 \mathrm{~h}$ each time) followed by $\mathrm{EtOH}-\mathrm{H}_{2} \mathrm{O}(7: 2)$. The extracts were filtered and pooled. After evaporation of EtOH in vacuo, the aqueous phase was extracted successively with hexane $(500 \mathrm{~mL} \times 5)$ and saturated $n-\mathrm{BuOH}$ with $\mathrm{H}_{2} \mathrm{O}(500 \mathrm{~mL} \times 5)$. The $n-\mathrm{BuOH}$ phase was decanted and evaporated in vacuo. The residue $(80 \mathrm{~g})$ was fractionated using an open Diaion $®$ column eluted with $\mathrm{H}_{2} \mathrm{O}-\mathrm{MeOH}$ with $30 \%, 50 \%$ and $80 \%$ of $\mathrm{MeOH}$. Three fractions were obtained: A (6.46 g), B (7.24 g) and C (58.96 g).

Fraction $\mathrm{C}$ was purified on silica gel $\mathrm{CC}$, eluted with $\mathrm{CHCl}_{3}-\mathrm{MeOH}$ gradient $(60: 1 \rightarrow 5: 1$, $\mathrm{v} / \mathrm{v})$ and three fractions were obtained. Fr. Cl (16.73 g) was subjected to silica gel using a gradient of $\mathrm{CHCl}_{3}-\mathrm{MeOH}(90: 1 \rightarrow 60: 1, \mathrm{v} / \mathrm{v})$ as eluent. Subfr. $\mathrm{Cl} .1(384 \mathrm{mg})$, obtained from $\mathrm{CHCl}_{3}-\mathrm{MeOH}(90: 1)$, was separated on silica gel $\mathrm{CC}$ with $\mathrm{CHCl}_{3}-\mathrm{MeOH}(80: 1)$ as eluent, 
to give three fractions. Subfr. C1.1A was purified by preparative HPLC with a gradient elution of $\mathrm{MeOH}-\mathrm{H}_{2} \mathrm{O}(50: 50 \rightarrow 85: 15, \mathrm{v} / \mathrm{v})$ yielding compounds $15(249 \mathrm{mg}), 16(5 \mathrm{mg})$ and $17(41 \mathrm{mg})$. Subfr. C1.1B (2.36 g) was applied successively on a silica gel CC and a reversed-phase $\mathrm{CC}$ using gradients $\mathrm{MeOH}-\mathrm{H}_{2} \mathrm{O}(50: 50 \rightarrow 70: 30, \mathrm{v} / \mathrm{v})$ as eluent to give 11 $(160 \mathrm{mg})$. Compound $9(3 \mathrm{mg}), 12(18 \mathrm{mg})$ and a mixture of 10 and $13(27 \mathrm{mg})$ were isolated after a silica gel $\mathrm{CC}$ eluted with $\mathrm{CHCl}_{3}-\mathrm{MeOH}(90: 1)$ and a preparative HPLC (isocratic $\mathrm{CH}_{3} \mathrm{CN}-\mathrm{H}_{2} \mathrm{O} 40: 60$ ) of Fr. C1.2. Compound 18 (50 mg) was obtained from fraction $\mathrm{Cl} .3(294 \mathrm{mg})$ after repeated silica gel $\mathrm{CC}\left(\mathrm{CHCl}_{3}-\mathrm{MeOH} 75: 1\right)$ and Polyamid flash column $\left(\mathrm{MeOH}-\mathrm{H}_{2} \mathrm{O}, 50: 50 \rightarrow 75: 25\right)$. Fr. C2 was chromatographed on silica gel CC with a gradient elution of $\mathrm{CHCl}_{3}-\mathrm{MeOH}(75: 1 \rightarrow 15: 1, \mathrm{v} / \mathrm{v})$ to give eight fractions. Subfr. C2.7 (558 mg) was separated by preparative HPLC using an isocratic mobile phase of $\mathrm{CH}_{3} \mathrm{CN}-\mathrm{H}_{2} \mathrm{O}-\mathrm{HCOOH}(40: 60: 1)$ to afford $2(19 \mathrm{mg})$ and $14(3 \mathrm{mg})$.

Fr. $\mathrm{C} 3(5.4 \mathrm{~g})$ was purified on silica gel using a gradient of $\mathrm{CHCl}_{3}-\mathrm{MeOH}(25: 1 \rightarrow 7: 1)$ for elution to give five subfractions. $\mathrm{C} 3.2$ was separated on silica gel $\mathrm{CC}$ with $\mathrm{CHCl}_{3}-\mathrm{MeOH}$ (20:1) giving $6(289 \mathrm{mg})$. Some purifications on different silica gel CC of subfr. C3.2.1 permitted to obtain $19(2 \mathrm{mg})$. Subfr. C3.4 (418 mg) was separated by preparative HPLC using an isocratic mobile phase of $\mathrm{CH}_{3} \mathrm{CN}-\mathrm{H}_{2} \mathrm{O}$ (30:70) to afford compounds 1 (20 mg), 3 ( $8 \mathrm{mg}), \mathbf{4}(14 \mathrm{mg})$ and 8 (37 mg). Subfr. C3.5 (482 mg) was separated by HPLC using a gradient of $\mathrm{MeOH}-\mathrm{H}_{2} \mathrm{O}(10: 90 \rightarrow 100: 0)$ to give $5(21 \mathrm{mg})$ and $7(35 \mathrm{mg})$. 


\section{(1S, 2S)-1-[4-O-E-coumaroyl- $\beta$-D-glucopyranosyloxy]cyclohexanediol} (1)

White amorphous powder; $[\alpha]_{D}^{25}-35.3^{\circ}$ (c 1.0, MeOH); IR (neat) $\mathrm{v}_{\max } 3328,2935,1696$, 1602, 1160, 1080, 1024, 982 and $833 \mathrm{~cm}^{-1} ;{ }^{1} \mathrm{H}$ and ${ }^{13} \mathrm{C}$ NMR spectroscopic data, see Table 2; HR-ESI-MS m/z 447.16225 [M+Na] (calcd for $\mathrm{C}_{21} \mathrm{H}_{28} \mathrm{O}_{9} \mathrm{Na}, 447.16310$ ).

\section{Acid hydrolysis of (1)}

Compound 1 was dissolved in $\mathrm{HCl} 10 \%$ and heated at $110^{\circ} \mathrm{C}$ for $4 \mathrm{~h}$. The resulting hydrolysate was extracted with $\mathrm{CHCl}_{3}$. The organic phase was dried $\left(\mathrm{MgSO}_{4}\right)$ and the solvent evaporated under reduced pressure. The presence of $p$-coumaric acid was confirmed with standard sample on TLC $\left(\mathrm{CHCl}_{3}-\mathrm{MeOH}\right.$ 10:1 as eluent and developing with NP/PEG reagent). The presence of cyclohexane-1,2-diol in the organic phase $\left(\alpha_{D}=+3.4\right)$ was confirmed with a GC-MS analysis: Injector temperature $250^{\circ} \mathrm{C}$; ionization voltage, $70 \mathrm{eV}$ (EI-MS); column temperature, $40^{\circ} \mathrm{C}$ for the initial 2 min followed by an increase of $15^{\circ} \mathrm{C}$ $\min ^{-1}$ up to $350^{\circ} \mathrm{C}$; carrier gas, He; column flow rate, $1 \mathrm{ml} \cdot \mathrm{min}^{-1}$. Cyclohexane-1,2-diol was detected at $R_{t} 7.55 \mathrm{~min}$. The aqueous phase was neutralized with $\mathrm{N}, \mathrm{N}$ dioctylmethylamine $\left(10 \%\right.$ in $\left.\mathrm{CHCl}_{3}\right)$ and the solvents were evaporated under reduced pressure. The residue contained the monosaccharide D-glucose $\left(\alpha_{D}=+24.8\right)$.

\section{Cell lines and culture conditions}

Lung carcinoma (A549), colorectal adenocarcinoma (DLD-1) and normal skin fibroblast (WS1) human cell lines were obtained from the American Type Culture Collection (ATCC). All cell lines were cultured in minimum essential medium containing Earle's salts and L-glutamine (Mediatech Cellgro, VA), to which were added $10 \%$ fetal bovine serum 
(Hyclone), vitamins (1X), penicillin (100 I.U. $\left.\mathrm{mL}^{-1}\right)$ and streptomycin $\left(100 \mu \mathrm{g} \mathrm{mL} \mathrm{m}^{-1}\right.$, essential amino acids (1X) and sodium pyruvate (1X) (Mediatech Cellgro, VA). Cells were kept at $37^{\circ} \mathrm{C}$ in a humidified environment containing $5 \% \mathrm{CO}_{2}$. Antibacterial activity was tested on Escherichia coli ATCC 25922 and Staphylococcus aureus ATCC 25923E.

\section{Cytotoxicity assay}

Exponentially growing cells were plated in 96-well microplates (BD Falcon) at a density of $5 \times 10^{3}$ cells per well in $100 \mu \mathrm{L}$ of culture medium (DMEM with $10 \%$ SVF) and were allowed to adhere for $24 \mathrm{~h}$ before treatment. Increasing concentrations of each compound in $\mathrm{MeOH}$ or DMSO were then added $(100 \mu \mathrm{L}$ per well) and the cells were incubated for $48 \mathrm{~h}$. The final concentration of $\mathrm{MeOH}$ or DMSO in the culture medium was maintained at 0.25 $\%(v / v)$ to avoid solvent toxicity. Cytotoxicity was assessed using resazurin (17) on an automated 96-well Fluoroskan Ascent $\mathrm{F} 1^{\mathrm{TM}}$ plate reader (Labsystems) using excitation and emission wavelengths of 530 and $590 \mathrm{~nm}$, respectively. Fluorescence was proportional to the cellular metabolic activity in each well. Survival percentage was defined as the fluorescence in experimental wells compared to that in control wells after subtraction of blank values. Each experiment was carried out thrice in triplicate. $\mathrm{IC}_{50}$ results were expressed as means \pm standard deviation.

\section{Antibacterial assays}

Antibacterial activity was evaluated using the microdilution method (42) but with some modifications: exponentially growing bacteria were plated in 96-well flat bottom microplates (BD Flacon) at a density of $5 \times 10^{3}$ gram-negative E. coli (ATCC 25922) or 
$40 \times 10^{3}$ gram-positive S. aureus (ATCC 25923) per well in $100 \mu \mathrm{L}$ nutrient broth (Difco). The concentration of ethanol in the culture medium was maintained at $0.25 \%(\mathrm{v} / \mathrm{v})$ to avoid solvent toxicity. Fifty microliters of $4 \%$ resazurin was added to each well and the microplates were incubated for $6 \mathrm{~h}$ at $37^{\circ} \mathrm{C}$. Fluorescence was measured after $6 \mathrm{~h}$ on an automated 96-well Fluoroskan Ascent Fl ${ }^{\mathrm{TM}}$ plate reader (Labsystems) using excitation and emission wavelengths of $530 \mathrm{~nm}$ and $590 \mathrm{~nm}$ respectively.

\section{Results and discussion}

The leaf buds of Populus tremuloides were extracted with EtOH and EtOH- $\mathrm{H}_{2} \mathrm{O}$ under reflux. After evaporation of EtOH in vacuo, the aqueous phase was successively partitioned with hexane and $n-\mathrm{BuOH}$. The $n-\mathrm{BuOH}$ soluble extract was purified on an open Diaion $\mathbb{R}$ column with a gradient of decreasing polarity and three fractions were obtained. Each fraction was investigated for in vitro cytotoxic and antibacterial biological activities. Cytotoxic activity evaluations were carried out on human lung cancer (A549), human colorectal cancer (DLD-1) and normal skin fibroblasts (WS1) using the resazurin reduction test as previously described in the literature (17). Antibacterial activity was evaluated against Escherichia coli and Staphylococcus aureus. The results (Table 1), show that the last fraction $\mathrm{C}$ was found to exert a weak cytotoxic activity against $\mathrm{A} 549\left(\mathrm{IC}_{50}, 96 \pm 7 \mu \mathrm{g}\right.$ $\left.\mathrm{mL}^{-1}\right)$ and DLD-1 $\left(\mathrm{IC}_{50}, 89 \pm 6 \mu \mathrm{g} \mathrm{mL}^{-1}\right)$, but was inactive toward bacterial cell lines. Thus, bioassay-guided fractionation of fraction $\mathrm{C}$ was undertaken with a combination of different chromatographic techniques leading to the isolation of a new compound 1 together with 18 known compounds (figure 1): chaenomeloidin (2) (18), prunin (3) (19), echinaticin (4) (20), 
echinacin (5) (21), tremulacin (6) (22), salicine (7) (23), tremuloidin (8) (24), genkwanin (9) (25), rhamnocitrin (10) (26), sakuranetin (11) (27), acacetin (12) (28), kaempferide (13) (29), aromadendrin (14) (30), phenylmethyl coumarate (15) (31), phenethyl p-coumàrate (16) (32), cinnamyl coumarate (17) (33), phenylmethyl caffeate (18) (34) and trans-ferulic acid (19) (35). Known compounds were identified by comparison of their spectroscopic data with the values found in the literature. NMR spectroscopic data for phenethyl $p$ coumarate (16), which was also isolated from buds of $P$. tremuloides, were not available. Therefore, complete ${ }^{1} \mathrm{H}$ and ${ }^{13} \mathrm{C}$ NMR spectroscopic data for 16 are also displayed.

Table 1: In vitro cytotoxicity and antibiotic results of the Diaion\& column's fractions ${ }^{a}$

\begin{tabular}{llllll}
\hline \multirow{2}{*}{ Samples } & \multicolumn{4}{c}{$\mathrm{IC}_{50}\left(\mu \mathrm{g} \mathrm{mL}^{-1}\right)^{\mathrm{b}}$} & \multicolumn{3}{l}{$\mathrm{MIC}^{\mathrm{c}}$} \\
\cline { 2 - 6 } & $\mathrm{A} 549$ & $\mathrm{DLD}-1$ & WS1 & S. aureus & E. coli \\
\hline Fraction A & $>100$ & $>100$ & $>100$ & $>100$ & $>100$ \\
Fraction B & $>100$ & $>100$ & $>100$ & $>100$ & $>100$ \\
Fraction C & $96 \pm 7$ & $89 \pm 6$ & $80 \pm 10$ & $>100$ & $>100$ \\
Etoposide $^{\mathrm{d}}$ & $2.8 \pm 0.5$ & $2 \pm 1$ & $>50$ & $\mathrm{NT}^{\mathrm{e}}$ & $\mathrm{NT}^{\mathrm{e}}$ \\
Chloramphenicol $^{\mathrm{d}}$ & $\mathrm{NT}^{\mathrm{e}}$ & $\mathrm{NT}^{\mathrm{e}}$ & $\mathrm{NT}^{\mathrm{e}}$ & $>5$ & $0.37 \pm 0.06$ \\
\hline
\end{tabular}

${ }^{a}$ Mean values ( \pm standard deviation) for triplicate assays.

${ }^{\mathrm{b}}$ Concentration of extract that caused $50 \%$ inhibition of cell proliferation.

${ }^{c}$ Minimum concentration of extract that resulted in inhibition of visible growth

${ }^{\mathrm{d}}$ Positive control.

${ }^{8}$ Not tested. 


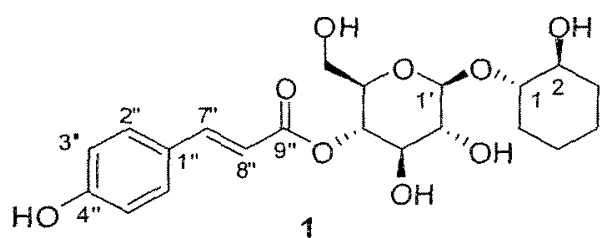<smiles>[R10][Z]1cc(O)c2c(c1)O[C@H](c1ccc(O)cc1)C([R])C2=O</smiles><smiles>[R]CC1O[C@H](Oc2cc(O)c3c(=O)cc(-c4ccc(O)cc4)oc3c2)[C@H](O)[C@@H](O)[C@@H]1[R]</smiles>

$4 \mathrm{R}^{1}=\mathrm{OH} ; \mathrm{R}^{2}=$ Coumaroyl $5 \mathrm{R}^{1}=$ Coumaroyl; $\mathrm{R}^{2}=\mathrm{OH}$<smiles>[R9]c1cc(O)c2c(=O)c([R])c(-c3cc[14c]([R10])cc3)oc2c1</smiles><smiles>[R]OC(=O)C=[C]c1ccc(O)c([R1])c1</smiles>

$15 \mathrm{R}^{1}=\mathrm{H} ; \mathrm{R}^{2}=\mathrm{CH}_{2}-\mathrm{Ph}$

$16 \mathrm{R}^{1}=\mathrm{H} ; \mathrm{R}^{2}=\mathrm{CH}_{2}-\mathrm{CH}_{2}-\mathrm{Ph}$

$17 \mathrm{R}^{1}=\mathrm{H} ; \mathrm{R}^{2}=\mathrm{CH}_{2}-\mathrm{CH}=\mathrm{CH}-\mathrm{Ph}$

$18 \mathrm{R}^{1}=\mathrm{OH} ; \mathrm{R}^{2}=\mathrm{CH}_{2}-\mathrm{Ph}$

$19 \mathrm{R}^{1}=\mathrm{OCH}_{3} ; \mathrm{R}^{2}=\mathrm{H}$<smiles>[R10]Cc1ccccc1O[C@H]1O[C@H](CO)[C@@H](O)[C@H]([R10])[C@H]1O[R2]</smiles>

$2 R^{1}=C O-P h ; R^{2}=H ; R^{3}=H$

$6 R^{1}=H ; R^{2}=$ CO $-P h ; R^{3}=$

$7 R^{1}=H ; R^{2}=H ; R^{3}=H$

$8 R^{3}=H ; R^{2}=C O-P h ; R^{3}=H$

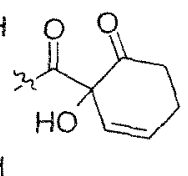

Figure 1: Polyphenols from Populus tremuloides

The molecular formula $\left(\mathrm{C}_{21} \mathrm{H}_{28} \mathrm{O}_{9}\right)$ of 1 , a white amorphous powder, was determined from its HR-ESI-MS spectrum (positive ion mode) on the basis of a quasimolecular ion peak at $\mathrm{m} / \mathrm{z} 447.1623[\mathrm{M}+\mathrm{Na}]^{+}$(calcd 447.1631). Infrared absorption bands at 3328, 1602, 1160,982 and $833 \mathrm{~cm}^{-1}$ suggested the presence of hydroxyl groups, aromatic system and an 
ester carbonyl groups. The ${ }^{13} \mathrm{C}$ NMR spectrum (Table 2) displayed 19 carbon signals separated by DEPT spectrum into five methylenes, seven aliphatic oxymethines, four unsaturated methines and three quaternary carbons (one for an ester carbonyl). Among them, six resonances could be assigned to a sugar moiety. The ${ }^{1} \mathrm{H}$ NMR spectrum confirmed the presence of a hexose moiety with anomeric proton at $\delta_{\mathrm{H}} 4.45(1 \mathrm{H}, \mathrm{d}, J=7.8$ $\mathrm{Hz}$ ). The ${ }^{1} \mathrm{H}$ NMR spectrum also shows the presence of two trans-olefinic protons at $\delta_{\mathrm{H}}$ $7.66(1 \mathrm{H}, \mathrm{d}, J=15.9 \mathrm{~Hz})$ and $\delta_{\mathrm{H}} 6.37(1 \mathrm{H}, \mathrm{d}, J=15.9 \mathrm{~Hz})$ and a 1,4-disubstituted aromatic rings with two protons at $\delta_{\mathrm{H}} 7.47(2 \mathrm{H}, \mathrm{d}, J=8.6 \mathrm{~Hz})$ and $6.81(2 \mathrm{H}, \mathrm{d}, J=8.6 \mathrm{~Hz})$. HMBC correlations at $\delta_{H} 7.47$ (H-2", H-6") and $\delta_{C} 147.3\left(\right.$ H-7"), $\delta_{H} 6.81$ (H-3", H-5") and $\delta_{C} 161.5$ $\left(\mathrm{C}-4^{\prime \prime}\right)$ and $\delta_{\mathrm{H}} 7.66\left(\mathrm{H}-7^{\prime \prime}\right)$ and $\delta_{\mathrm{C}} 168.6\left(\mathrm{C}-9^{\prime \prime}\right)$ suggested the presence of a coumaroyl moiety. Analysis of the COSY, HSQC and HMBC spectra led to the identification of a third aglycone sytem: the cyclohexane-1,2-diol. HMBC correlation between the methine proton at $\delta_{\mathrm{H}} 4.87\left(\mathrm{H}^{-} 4^{\prime}\right)$ and the carbonyl group at $\delta_{\mathrm{C}} 168.6\left(\mathrm{C}-9^{\prime \prime}\right)$ suggested the linkage between the glucose and the coumaroyl moiety. Finally, the correlation between $\delta_{\mathrm{H}} 4.45$ $\left(\mathrm{H}-\mathrm{l}^{\prime}\right)$ and $\delta_{\mathrm{C}} 79.4(\mathrm{C}-1)$, indicated the linkage site of the glucose moiety to the aglycone.

Acidic hydrolysis of $\mathbf{1}$ and TLC analysis of the aqueous phase afforded identification of glucose as the sugar component. Absolute configuration of the glucose as D was determined by optical rotations in comparison with authentic standard. The presence of $p$-coumaric acid in the organic phase was confirmed by TLC in comparison with authentic standard. Cyclohexane-1,2-diol was also detected in the organic phase using GC-MS and NMR analysis (36). The absolute configuration of cyclohexane-1,2-diol could be determined directly from the organic phase since the other aglycon part, namely p-coumaric acid, is 
optically inactive. The organic phase showed positive value in optical activity measurement meaning that (1S,2S)-cyclohexane-1,2-diol has been isolated (37). The structure of 1 was thus confirmed as $(1 S, 2 S)-1-[4-O-E$-coumaroyl- $\beta$-D-glucopyranosyloxy]cyclohexanediol.

Table 2: ${ }^{1} \mathrm{H}(400 \mathrm{MHz})$ and ${ }^{13} \mathrm{C}$ NMR $(100 \mathrm{MHz})$ spectroscopic data for compound 1 in methanol- $\mathrm{d}_{4}$.

\begin{tabular}{lll}
\hline Position & $\delta_{\mathrm{C}}$ (mult.) $)^{\mathrm{a}}$ & $\delta_{\mathrm{H}}$ (mult., $J$ in Hz) \\
\hline 1 & $79.4(d)$ & $3.87(\mathrm{~m})$ \\
2 & $71.0(d)$ & $3.85(\mathrm{~m})$ \\
3 & $31.5(t)$ & $1.79(\mathrm{~m})$ \\
& & $1.55(\mathrm{~m})$ \\
4 & $22.4(t)$ & $1.65(\mathrm{~m})$ \\
& & $1.34(\mathrm{~m})$ \\
5 & $23.1(t)$ & $1.71(\mathrm{~m})$ \\
& & $1.31(\mathrm{~m})$ \\
6 & $27.6(t)$ & $1.82(\mathrm{~m})$ \\
& & $1.63(\mathrm{~m})$ \\
$1^{\prime}$ & $102.2(d)$ & $4.45,(d, 7.8)$ \\
$2^{\prime}$ & $75.1(d)$ & $3.35(d d, 9.3,7.8)$ \\
$3^{\prime}$ & $75.6(d)$ & $3.65(t, 9.3)$ \\
$4^{\prime}$ & $72.5(d)$ & $4.87(\mathrm{~m})$ \\
$5^{\prime}$ & $76.1(d)$ & $3.53(\mathrm{~m})$ \\
$6^{\prime}$ & $62.4(t)$ & $3.62(d d, 15.0,5.4)$ \\
& & $3.54(\mathrm{~m})$ \\
$1^{\prime \prime}$ & $127.2(\mathrm{~s})$ & \\
$2^{\prime \prime}, 6^{\prime \prime}$ & $131.3(d)$ & $7.47(d, 8.6)$ \\
$3^{\prime \prime}, 5^{\prime \prime}$ & $116.9(d)$ & $6.81(d, 8.6)$ \\
$4^{\prime \prime}$ & $161.5(s)$ & \\
$7^{\prime \prime}$ & $147.3(d)$ & $7.66(d, 15.9)$ \\
$8^{\prime \prime}$ & $114.8(d)$ & $6.37(d, 15.9)$ \\
$9^{\prime \prime}$ & $168.6(\mathrm{~s})$ & \\
\hline
\end{tabular}

${ }^{a}$ Multiplicities were deduced from DEPT experiments 
Compound 16 has been identified by many authors but surprisingly, no complete NMR assignation was given (38). Therefore, complete ${ }^{1} \mathrm{H}$ and ${ }^{13} \mathrm{C}$ characterisation was accomplished using ${ }^{1} \mathrm{H},{ }^{13} \mathrm{C}$ and $2 \mathrm{D}$ spectra (Table 3). First, the same $p$-coumaroyl moieties as in 1 was identified with $\delta_{\mathrm{H}}$ at $6.29(1 \mathrm{H}, \mathrm{d}, J=15.9 \mathrm{~Hz}, \mathrm{H}-8), 6.85(2 \mathrm{H}, \mathrm{d}, J=8.1 \mathrm{~Hz}, \mathrm{H}-$ 3 and $\mathrm{H}-5), 7.42(2 \mathrm{H}, \mathrm{d}, J=8.1 \mathrm{~Hz}, \mathrm{H}-2$ and $\mathrm{H}-6)$ and $7.62(1 \mathrm{H}, \mathrm{d}, J=15.9 \mathrm{~Hz}, \mathrm{H}-7)$ and $\delta_{\mathrm{C}}$ at $115.5(\mathrm{C}-8), 115.9(\mathrm{C}-3$ and C-5), $127.3(\mathrm{C}-1), 130.0$ (C-2 and C-6), $144.6(\mathrm{C}-7)$, $157.7(\mathrm{C}-4)$ and $167.4(\mathrm{C}-9)$.

Table 3: ${ }^{1} \mathrm{H}(400 \mathrm{MHz})$ and ${ }^{13} \mathrm{C}$ NMR $(100 \mathrm{MHz})$ spectroscopic data for compound 16 in methanol- $\mathrm{d}_{4}$.

\begin{tabular}{lll}
\hline Position & $\delta_{\mathrm{C}}(\text { mult. })^{\mathrm{a}}$ & $\delta_{\mathrm{H}}$ (mult., $J$ in Hz) \\
\hline 1 & $127.3(s)$ & \\
2,6 & $130.0(d)$ & $7.42(d, 8.1)$ \\
3,5 & $115.9(d)$ & $6.85(d, 8.1)$ \\
4 & $157.7(s)$ & \\
7 & $144.6(d)$ & $7.62(d, 15.9)$ \\
8 & $115.5(d)$ & $6.29(d, 15.9)$ \\
9 & $167.4(s)$ & \\
$1^{\prime}$ & $137.9(s)$ & \\
$2^{\prime}, 6^{\prime}$ & $128.9(d)$ & $7.26(m)$ \\
$3^{\prime}, 5^{\prime}$ & $128.5(d)$ & $7.32(m)$ \\
$4^{\prime}$ & $126.6(d)$ & $7.25(m)$ \\
$7^{\prime}$ & $35.2(t)$ & $3.02(t, 6.9)$ \\
$8^{\prime}$ & $65.0(t)$ & $4.42(t, 6.9)$ \\
\hline
\end{tabular}

${ }^{a}$ Multiplicities were deduced from DEPT experiments 
Table 4: In vitro cytotoxicity results of isolated compounds (1-19)

\begin{tabular}{|c|c|c|c|}
\hline \multirow{2}{*}{ Compounds } & \multicolumn{3}{|c|}{$\mathrm{IC}_{50}(\mu \mathrm{M} \pm \mathrm{SD})^{\mathrm{b}}$} \\
\hline & A549 & DLD-1 & WS1 \\
\hline 1 & $>100$ & $>100$ & $>100$ \\
\hline 2 & $\mathrm{NT}^{\mathrm{c}}$ & $\mathrm{NT}^{\mathrm{c}}$ & $\mathrm{NT}^{\mathrm{c}}$ \\
\hline 3 & $>100$ & $>100$ & $>100$ \\
\hline 4 & $\mathrm{NT}^{\mathrm{c}}$ & $\mathrm{NT}^{\mathrm{c}}$ & $N T^{c}$ \\
\hline 5 & $>100$ & $>100$ & $42 \pm 4$ \\
\hline 6 & $>100$ & $>100$ & $>100$ \\
\hline 7 & $>100$ & $>100$ & $>100$ \\
\hline 8 & $81 \pm 3$ & $>100$ & $>100$ \\
\hline 9 & $9 \pm 3$ & $9.2 \pm 0.9$ & $5.8 \pm 0.3$ \\
\hline 10 & $31 \pm 2$ & $37 \pm 3$ & $87 \pm 3$ \\
\hline 11 & $>100$ & $>100$ & $>100$ \\
\hline 12 & $27 \pm 3$ & $23 \pm 6$ & $20 \pm 2$ \\
\hline 13 & $60 \pm 10$ & $>100$ & $42 \pm 5$ \\
\hline 14 & $>100$ & $>100$ & $>100$ \\
\hline 15 & $19 \pm 2$ & $19.2 \pm 0.9$ & $26 \pm 3$ \\
\hline 16 & $>100$ & $>100$ & $>100$ \\
\hline 17 & $>100$ & $>100$ & $>100$ \\
\hline 18 & $45.8 \pm 0.9$ & $39 \pm 3$ & $51 \pm 7$ \\
\hline 19 & $>100$ & $>100$ & $>100$ \\
\hline Etoposide $^{d}$ & $2.8 \pm 0.5$ & $2 \pm 1$ & $>50$ \\
\hline
\end{tabular}

${ }^{a}$ Mean values ( \pm standard deviation) for triplicate assays.

${ }^{b}$ Concentration that caused $50 \%$ inhibition of cell proliferation.

${ }^{c}$ Not tested.

d Positive control. 
Additionally, five overlapped ${ }^{1} \mathrm{H}$ NMR signals between $\delta_{\mathrm{H}} 7.20-7.30$ along with two methylene triplets at $3.02\left(2 \mathrm{H}, \mathrm{t}, J=6.9 \mathrm{~Hz}, \mathrm{H}-7^{\prime}\right)$ and $4.42\left(2 \mathrm{H}, \mathrm{t}, J=6.9 \mathrm{~Hz}, \mathrm{H}-8^{\circ}\right)$ were attributed to a phenethyl moiety. The HMBC correlation between $\mathrm{H}-8^{\prime}$ and $\mathrm{C}-9$ confirmed the link between the phenethyl and the p-coumaroyl groups.

Compounds 10 and 13 were isolated as a mixture. Separation of each constituent was not performed due to their low amounts. Therefore, careful examination of NMR spectra $\left({ }^{1} \mathrm{H}\right.$, ${ }^{13} \mathrm{C}, \mathrm{DEPT}$ and $\mathrm{HSQC}$ ) and comparison with literature allowed the identification of these components as rhamnocitrin (10) (29) and kaempferide (13) (26). Moreover, the biological results were obtained using commercial pure products. Because of low isolated yields of compounds 3 and 19 , those compounds were also tested from commercial materials.

All isolated compounds, except compounds 2 and 4 , were evaluated using resazurin reduction test for their cytotoxicity against human lung cancer (A549), human colorectal cancer (DLD-1) and normal skin fibroblasts (WS1) (17). Results presented in Table 4 are expressed as the concentration of product inhibiting cell growth by $50 \%\left(\mathrm{IC}_{50}\right)$. Etoposide was used as positive control with $\mathrm{IC}_{50}$ of 2.8 and $2.0 \mu \mathrm{M}$ against $\mathrm{A} 549$ and $\mathrm{DLD}-1$ cell lines, respectively. The phenolic compounds were regarded as active when the $\mathrm{IC}_{50}$ was smaller than $100 \mu \mathrm{M}$ (39). The compound 9 was found the most active with $\mathrm{IC}_{50}$ ranging from 5.8 to $9.2 \mu \mathrm{M}$. Moreover, compounds 10,12 and 15 were moderately active against cancer cells with $\mathrm{IC}_{50}$ ranging from 19 to $37 \mu \mathrm{M}$. In contrast to compounds $\mathbf{9 , 1 2}$ and $\mathbf{1 5}$, the compound 10 was significantly selective toward cancer cells with $\mathrm{IC}_{50}$ of $31 \mu \mathrm{M}$ for A549 and $37 \mu \mathrm{M}$ for DLD-1 in comparison to $87 \mu \mathrm{M}$ for normal cells, WS1. Although the 
cytotoxicity of compounds 9 and 12 were known on A549 cells (40-41), the activity on human colorectal adenocarcinoma DLD-1 was never reported. Finally, compounds $\mathbf{1 3}$ and 18 were found weakly cytotoxic and all the other compounds tested were inactive. As far as structure-activity relationships are concerned, these in vitro results suggest that the addition of a double bond in $\mathrm{C}-2$ position in molecule 9 , with regard to the compound $\mathbf{1 1}$, increases the cytotoxic activity. Similarly, the presence of a methoxy group in $\mathrm{C}-7$ position and a hydroxyl in C-4' position in the flavone 9, seem to have a beneficial effect on the cytotoxic activity in comparison with the acacetin (12), where the inversion of these groups reduces the activity. On the other hand, the presence of hydroxyl group in $\mathrm{R}^{2}$ of compounds $\mathbf{1 0}$ and 13 is detrimental for the activity in comparison with compounds 9 and 12 , respectively. In the case of compounds 15-19, only molecules bearing a benzyl groups exhibited cytotoxicities (15 and 18). Moreover, hydroxyl group in $\mathrm{R}^{1}$ of compound 18 reduces significantly the cytotoxicity in comparison to 15. All compounds were also evaluated for their antibacterial activities against $S$. aureus and $E$. coli but no significant activity was observed.

\section{Concluding remarks}

In conclusion, the structure of a new compound 1 was described and 19 compounds were identified from $P$. tremuloides. Among them, compounds $\mathbf{2}$ and $\mathbf{5}$ were reported for the first time in Populus genus and compounds 3, 4, 9, 10, 12, 16 and 17 for the first time in Populus tremuloides. Compound 9 was found the most cytotoxic against lung carcinoma cell (A549) and colorectal adenocarcinoma (DLD-1) human cell lines. Interestingly, the 
compound 10 was selective toward both cancer cell lines in comparison to normal cells.

Finally, all compounds tested do not possess antibacterial activity.

\section{Acknowledgement}

The financial support of Fonds Québécois de la Recherche sur la Nature et les Technologies (FQRNT, fonds forestiers 02) is gratefully acknowledged. The authors wish to thank Carole Grenon for the HPLC separations, Catherine Dussault and Maxime Lebrun for biological assays. Finally, the authors also thank Dr Richard Menini for his corrections and helpful comments on this manuscript

\section{References}

(1) Marcucci, M. C. Apidologie 1995, 26, 83. doi: 10.1051/apido:19950202.

(2) Kujumgiev, A.; Tsvetkova, I.; Serkedjieva, Y.; Bankova, V.; Christov, R.; Popov, S. J.

Ethnopharmacol. 1999, 64, 235. doi: 10.1016/S0378-8741(98)00131-7.

(3) Nieva Moreno, M. I.; Isla, M. I.; Cudmani, N. G.; Vattuone, M. A.; Sampietro, A. R. J. Ethnopharmacol. 1999, 68, 97. doi: 10.1016/S0378-8741(99)00051-3.

(4) Sforcin, J. M.; Fernandes Jr, A.; Lopes, C. A. M.; Bankova, V.; Funari, S. R. C. J. Ethnopharmacol. 2000, 73, 243. doi: 10.1016/S0378-8741(00)00320-2.

(5) Miyataka, H.; Nishiki, M.; Matsumoto, H.; Fujimoto, T.; Matsuka, M.; Satoh, T. Biol. Pharm. Bull. 1997, 20, 496. url: http:/ci.nii.ac.jp/naid/110003639087/en/.

(6) Orhan, H.; Marol, S.; Hepsen, I. F.; Sahin, G. Toxicology 1999, 139, 219. doi: 10.1016/S0300-483X(99)00128-6.

(7) Volpert, R.; Elstner, E. F. Z. Naturforsch., C: J. Biosci. 1993, 48, 851.

(8) Banskota, A. H.; Tezuka, Y.; Prasain, J. K.; Matsushige, K.; Saiki, I.; Kadota, S. J. Nat. Prod. 1998, 61, 896. doi: 10.1021/np980028c. 
(9) Popova, M.; Bankova, V.; Butovska, D.; Petkov, V.; Nikolova-Damyanova, B.;

Sabatini, A. G.; Marcazzan, G. L.; Bogdanov, S. Phytochem. Anal. 2004, 15, 235. doi: 10.1002.pca.777.

(10) Silici, S.; Kutluca, S. J. Ethnopharmacol. 2005, 99, 69. doi: 10.1016/j.jep.2005.01.046.

(11) English, S.; Greenaway, W.; Whatley, F. R. Can. J. Bot. 1991, 69, 2291. doi: 10.1139/b91-288.

(12) Greenaway, W.; May, J.; Whatley, F. R. J. Chromatogr. A 1989, 472, 393. doi: 10.1016/S0021-9673(00)94139-6.

(13) Hashimoto, T.; Tori, M.; Asakawa, Y.; Wollenweber, E. Z. Naturforsch., C: J. Biosci. $1988,43,470$.

(14) Christov, R.; Trusheva, B.; Popova, M.; Bankova, V.; Bertrand, M. Nat. Prod. Res. 2005, 19, 673. doi: 10.1080/14786410512331328159.

(15) Burns, R. M.; Honkala, B. H. Silvics of North America 1990. United States Department of Agriculture, Forest Service, Washington, DC. url: www.na.fs.fed.us/spfo/pubs/silvics_manual/volume_2/populus/tremuloides.htm.

(16) Moerman, D. E., Native american ethnobotany. 1998, Timber Press Inc.

(17) O'Brien, J.; Wilson, I.; Orton, T.; Pognan, F. Eur. J. Biochem. 2000, 267, 5421. doi: 10.1046/j.1432-1327.2000.01606.x.

(18) Mizuno, M.; Kato, M.; Misu, C.; Iinuma, M.; Tanaka, T. J. Nat. Prod. 1991, 54, 1447. doi: $10.1021 / \mathrm{np} 50077 \mathrm{a} 042$.

(19) Lewinsohn, E.; Berman, E.; Mazur, Y.; Gressel, J. Phytochemistry 1986, 25, 2531. doi: $10.1016 / \mathrm{S} 0031-9422(00) 84502-1$.

(20) Singh, K. N.; Pandey, V. B.; Banerjee, S.; Bohlmann, F.; Keinan, E. Chem. Ind. 1986, 713.

(21) Güvenalp, Z.; Özbek, H.; Ünsalar, T.; Kazaz, C.; Demirezer, L. Ö. Turk. J. Chem. 2006, 30, 391. url: http:/journals.tubitak.gov.tr/chem/issues/kim-06-30-3/kim-30-3-130511-5.pdf.

(22) Rasmussen, B.; Nkurunziza, A. J.; Witt, M.; Oketch-Rabah, H. A.; Jaroszewski, J. W.; Staerk, D. J. Nat. Prod. 2006, 69, 1300. doi: 10.1021/np060204e. 
(23) Otsuka, H.; Yamasaki, K.; Yamauchi, T. Phytochemistry 1989, 28, 3197. doi:

10.1016/0031-9422(89)80306-1.

(24) Ishikawa, T.; Nishigaya, K.; Takami, K.; Uchikoshi, H.; Chen, I.-S.; Tsai, I.-L. J. Nat.

Prod. 2004, 67, 659. doi: 10.1021/np034052o.

(25) Zahir, A.; Jossang, A.; Bodo, B.; Provost, J.; Cosson, J.-P.; Sevenet, T. J. Nat. Prod. 1996, 59, 701. doi: 10.1021/np960336f.

(26) Sakakibara, M.; Difeo Jr, D.; Nakatani, N.; Timmermann, B.; Mabry, T.J.

Phytochemistry 1976, 15, 727. doi: 10.1016/S0031-9422(00)94430-3

(27) Perry, N.B.; Foster, L.M. Planta Med. 1994, 60, 491. doi: 10.1055/s-2006-959549.

(28) Tian, F,; McLaughlin, J.L. Pharm. Biol. 2000, 38, 229. doi: 10.1076/13880209(200007)38:3;1-S;FT229.

(29) Majumder, P.L.; Chattopadhyay, A. J. Indian Chem. Soc. 1985, 62, 616.

(30) Mánez, S.; Paya, M.; Terencio, C.; Villar, A. Planta Med. 1988, 187. doi: 10.1055/s2006-962396.

(31) El-Batta, A.; Jiang, C.; Zhao, W.; Anness, R.; Cooksy, A.L.; Bergdahl, M. J. Org. Chem. 2007, 72, 5244. doi: 10.1021/jo070665k.

(32) English, S.; Greenaway, W.; Whatley, F.R. Phytochemistry 1992, 31, 1255. doi: 10.1016/0031-9422(92)80272-G.

(33) Mali, R.S.; Papalkar, A.S. J. Chem. Res. 2001, S433. doi: $10.3184 / 030823401103168370$.

(34) Yamauchi, R.; Kato, K.; Oida, S.; Kanaeda, J.; Ueno, Y. Biosci., Biotechnol., Biochem. 1992, 56, 1321. url: http://www.journalarchive.jst.go.jp/jnlpdf.php?cdjournal=bbb1992\&cdvol=56\&noissue $=8 \&$ startpage $=1321 \&$ lang $=$ en $\&$ from $=$ jnlabstract

(35) Kelley, C.J.; Harruff, R.C.; Carmack, M.J. Org. Chem. 1976, 41, 449. doi: $10.1021 / \mathrm{j} 000865 \mathrm{a} 007$.

(36) Pouchert, C. J., 1983. The Aldrich Library of NMR Spectra. Edition II. p. 160.

(37) Porwoll, J., 2007. Handbook of Fine Chemicals. Aldrich Chemical Co., Milwaukee, MI. url: 
http://www.sigmaaldrich.com/catalog/ProductDetail.do?lang=en\&N4=421804|ALDRIC $\mathrm{H} \& N 5=\mathrm{SEARCH} \_C O N C A T \_P N O \mid B R A N D \_K E Y \& F=S P E C$

(38) Lee, Y.-T.; Don, M.-J.; Hung, P.-S.; Shen, Y.-C.; Lo, Y.-S.; Chang, K.-W.; Chen, C.F.; Ho, L.-K. Cancer Lett. 2005, 223, 19. doi: 10.1016/j.canlet.2004.09.048.

(39) Boyd, M. R. In Anticancer Drug Development Guide: Preclinical Screening. Clinical Trials, and Approval; Teicher, B. A., Ed.; Humana Press: Totowa, NJ, 2004, pp. 41-62. (40) Nagaoka, T.; Banskota, A.H.; Tezuka, Y.; Saiki, I.; Kadota, S. Bioorg. Med. Chem. 2002, 10, 3351. doi: 10.1016/S0968-0896(02)00138-4.

(41) Ryu, S.Y.; Kim, J.O.; Choi, S.U. Planta Med. 1997, 63, 384. doi: 10.1055/s-2006957714.

(42) Banfi, E.; Scialino, G.; Monti-Bragadin, C. J. Antimicrob. Chemother. 2003, 52, 796. doi: $10.1093 / \mathrm{jac} / \mathrm{dkg} 439$. 
Chapter IV

\section{RESULTS AND DISCUSSION:}

Other results related to phytochemical study of

Populus tremuloides 
This chapter is devoted to the detailing of another five purified molecules found in this species which are not mentioned in chapter III. Thus, other processes of isolation and characterisation of interesting fractions will be discussed here. In addition, the performed biological assays which were not presented so far will be explained in the next sections.

\subsection{Isolation and purification of phenolic compounds}

Fraction $\mathrm{C} 2(12.5 \mathrm{~g})$ was chromatographed on silica gel column chromatography (CC) using gradient $\mathrm{CHCl}_{3}-\mathrm{MeOH}(75: 1 \rightarrow 15: 1, \mathrm{v} / \mathrm{v})$ as eluent to give pure $22(630 \mathrm{mg})$. Subfraction $\mathrm{C} 2.3$ was further separated on silica gel $\mathrm{CC}$ using $\mathrm{CHCl}_{3}-\mathrm{MeOH}$ gradient $(40: 1$

$\rightarrow 25: 1)$ as eluent to yield compound $21(16 \mathrm{mg})$. Subfraction $\mathrm{C} 2.7$ was purified by preparative HPLC using an isocratic mobile phase of $\mathrm{CH}_{3} \mathrm{CN}-\mathrm{H}_{2} \mathrm{O}(40: 60)$ to afford pures $20(11 \mathrm{mg})$ and $24(11 \mathrm{mg})$. Fraction C3 (10.37 g) was separated on silica gel CC using $\mathrm{CHCl}_{3}-\mathrm{MeOH}$ gradient $(15: 1 \rightarrow 7: 1, \mathrm{v} / \mathrm{v})$ as eluent to give 5 fractions. Then, subfraction C3.2 (1.19 g) was separated into four fractions by passage over silica gel, eluted with $\mathrm{CHCl}_{3}-\mathrm{MeOH}(20: 1)$ and pure $23(11 \mathrm{mg})$ was obtained by preparative HPLC, gradient $\mathrm{MeOH}-\mathrm{H} 2 \mathrm{O}(50: 50 \rightarrow 70: 30, \mathrm{v} / \mathrm{v})$

\subsection{Identifiation of purified phenolic compounds}

The phenolic compounds presented in figure $5(\mathbf{2 0 - 2 4})$ have been identified mainly by their ${ }^{1} \mathrm{H}$ and ${ }^{13} \mathrm{C}$ NMR spectral data and their molecular formula. These compounds are newly identified products in the P.tremuloides and compounds 20 and 24 were never reported for family of Salicaceae. 


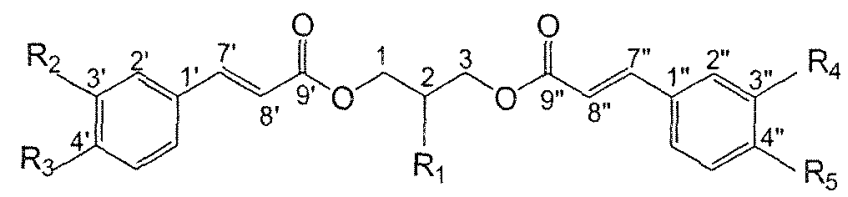

$20 R_{1}, R_{3}, R_{5}=O H ; R_{2}, R_{4}=H$

$21 R_{1}=O A C ; R_{2}, R_{4}=H ; R_{3}, R_{5}=O H$

$22 R_{1}=O A C ; R_{2}=H ; R_{3}, R_{4}, R_{5}=O H$

$23 R_{1}=O A C ; R_{2}, R_{3}, R_{4}, R_{5}=O H$<smiles>CC(C=Cc1ccc(O)cc1)OC(=O)C=CC(=O)OC(C)CO</smiles>

24

Figure 5: Five phenolic compounds from buds of $P$. tremuloides.

\subsubsection{Identification of compound 20}

The ${ }^{1} \mathrm{H}$ and ${ }^{13} \mathrm{C}$ NMR spectra of compound 20 showed the presence of two equivalent $p$ coumarate moieties as one doublet at $\delta_{\mathrm{H}} 7.44(2 \mathrm{H}, \mathrm{d}, J=8.6 \mathrm{~Hz})$ and $6.80(2 \mathrm{H}, \mathrm{d}, J=8.6 \mathrm{~Hz})$ for aromatic rings and $\delta_{\mathrm{H}} 7.66(1 \mathrm{H}, \mathrm{d}, J=15.9 \mathrm{~Hz})$ and $6.35(1 \mathrm{H}, \mathrm{d}, \mathrm{J}=15.9 \mathrm{~Hz})$ for alkene function (confirmed by ${ }^{13} \mathrm{C}$ NMR spectrum) of trans geometry. Remaining signals $\delta_{\mathrm{H}} 4.28-$ $4.16(5 \mathrm{H}, \mathrm{m})$ in the ${ }^{1} \mathrm{H}$ NMR and $\delta_{\mathrm{C}} 66.2(\mathrm{t})$ and $68.4(\mathrm{~d})$ in the ${ }^{13} \mathrm{C}$ NMR spectra suggested the presence of a 1,3-0-di-trans-p-coumaroylglycerol. Spectroscopic data of compounds 20 were in agreement with the values reported in the literature [55]. 
Table 3: ${ }^{1} \mathrm{H}$ and ${ }^{13} \mathrm{C}$ NMR spectroscopic data for compound 20 in methanol-d4.

\begin{tabular}{lll}
\hline Position & $\delta_{\mathrm{C}}($ mult.) & $\delta_{\mathrm{H}}$ (mult., $J$ in Hz) \\
\hline 1 & $66.2(\mathrm{t})$ & $4.28(\mathrm{br} \mathrm{d}, 5.2)$ \\
2 & $68.4(\mathrm{~d})$ & $4.16($ quint, 5.2$)$ \\
$1^{\prime}$ & $126.9(\mathrm{~s})$ & \\
$2^{\prime}$ & $131.1(\mathrm{~d})$ & $7.44(\mathrm{~d}, 8.6)$ \\
$3^{\prime}$ & $116.7(\mathrm{~d})$ & $6.80(\mathrm{~d}, 8.6)$ \\
$4^{\prime}$ & $161.1(\mathrm{~s})$ & \\
$7^{\prime}$ & $146.9(\mathrm{~d})$ & $7.66(\mathrm{~d}, 15.9)$ \\
$8^{\prime}$ & $114.7(\mathrm{~d})$ & $6.35(\mathrm{~d}, 15.9)$ \\
$9^{\prime}$ & $168.9(\mathrm{~s})$ & \\
\hline
\end{tabular}

\subsubsection{Identification of compound 21}

The ${ }^{1} \mathrm{H}$ and ${ }^{13} \mathrm{C}$ NMR spectra of compound 21 indicated the same structure as pure 20 (1,3-O-Di-trans- $p$-coumaroylglycerol) excepted for a difference in the triglycerol moiety. These spectra data (see table 4) confirmed the presence of an acetyl group; $\delta_{\mathrm{H}} 2.08(3 \mathrm{H}, \mathrm{s})$, $\delta_{\mathrm{C}} 20.9$ (COCH3), 172 (COCH3), at C-2 of 21 instead of hydroxyl group as in 20 . This was ascertained by ${ }^{1} \mathrm{H}{ }^{1} \mathrm{H}$ COSY, HMQC and HMBC correlations designed by arrows in figure 6. This molecule is named as 2-acetyl-1,3-dicoumaroylglycerol (Lasiocarpin A) and the spectroscopic data of compound $\mathbf{2 1}$ were in agreement with the values reported in the literature [56]. 


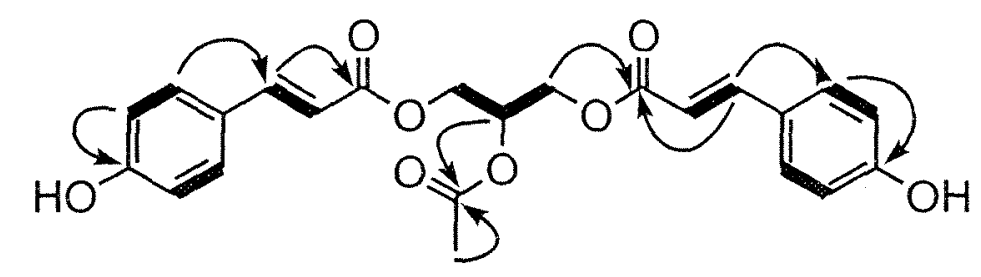

Figure 6: ${ }^{1} \mathrm{H}{ }^{1} \mathrm{H}$ COSY, HMQC and HMBC correlations (21).

Table 4: ${ }^{1} \mathrm{H}$ and ${ }^{13} \mathrm{C}$ NMR spectroscopic data for compound 21 in methanol-d4.

\begin{tabular}{cccc}
\hline Position & $\delta_{\mathrm{C}}($ mult.) & $\delta_{\mathrm{H}}($ mult., $J$ in $\mathrm{Hz})$ & $\delta_{\mathrm{H}}($ mult., $J$ in $\mathrm{Hz})$ \\
\hline 1 & $63.5(\mathrm{t})$ & $4.47(\mathrm{dd}, 12.1,4.1)$ & $4.35(\mathrm{dd}, 12.1,5.9)$ \\
2 & $71.0(\mathrm{~d})$ & $5.37(\mathrm{~m})$ & - \\
$1^{\prime}$ & $127.1(\mathrm{~s})$ & - & - \\
$2^{\prime}$ & $131.4(\mathrm{~d})$ & $7.45(\mathrm{~d}, 8.7)$ & - \\
$3^{\prime}$ & $116.9(\mathrm{~d})$ & $6.79(\mathrm{~d}, 8.7)$ & - \\
$4^{\prime}$ & $161.5(\mathrm{~s})$ & - & - \\
$7^{\prime}$ & $147.3(\mathrm{~d})$ & $7.63(\mathrm{~d}, 15.9)$ & - \\
$8^{\prime}$ & $114.5(\mathrm{~d})$ & $6.34(\mathrm{~d}, 15.9)$ & - \\
$9^{\prime}$ & $168.7(\mathrm{~s})$ & - & - \\
$\mathrm{Ac}$ & - & - & - \\
$\mathrm{CO}$ & $172.0(\mathrm{~s})$ & - & - \\
$\mathrm{Me}$ & $20.9(\mathrm{q})$ & $2.08(\mathrm{~s})$ & - \\
\hline
\end{tabular}




\subsubsection{Identification of compound 22}

The ${ }^{1} \mathrm{H}$ and ${ }^{13} \mathrm{C}$ NMR spectra of compound 22, with $[\alpha] \mathrm{D}^{25} 3.16^{\circ}(c=0.5, \mathrm{MeOH})$, were found to be similar to those of 21 , except for a difference in one of the benzene rings with three protons as one singulet at C-2" $\delta_{\mathrm{H}} 7.04(1 \mathrm{H}, \mathrm{s})$, one doublet at $\mathrm{C}-5 " \delta_{\mathrm{H}} 6.77(2 \mathrm{H}$, $\mathrm{d}, \mathrm{J}=8.4 \mathrm{~Hz})$, and two other as one doublet at C-6" $\delta_{\mathrm{H}} 6.95(2 \mathrm{H}, \mathrm{d}, \mathrm{J}=8.3 \mathrm{~Hz})$. These spectral data (see table 5) indicated the presence of a hydroxyl group at C-3" of 22 instead of two $p$-coumaroyl groups in 21. Additionally, the presence of two double bound protons signals at $\delta_{\mathrm{H}} 7.63(1 \mathrm{H}, \mathrm{d}, J=15.9 \mathrm{~Hz}), \delta_{\mathrm{H}} 6.34(1 \mathrm{H}, \mathrm{d}, J=15.9 \mathrm{~Hz})$ and $\delta_{\mathrm{H}} 7.57(1 \mathrm{H}, \mathrm{d}, J=$ $15.9 \mathrm{~Hz}), \delta_{\mathrm{H}} 6.27(1 \mathrm{H}, \mathrm{d}, J=15.9 \mathrm{~Hz})$ demonstrated that 2-acetyl-1-caffoyl-3coumaroylglycerol (lasiocarpin B) was an asymmetrical triglyceride with acetic, $p$ hydroxycinnamic and 3,4-dihydroxy cinnamic acids (figure 6). The spectroscopic data of compound 22 were in agreement with the values reported in the literature [56]. 
Table 5: ${ }^{1} \mathrm{H}$ and ${ }^{13} \mathrm{C}$ NMR spectroscopic data for compound 22 in methanol-d4.

\begin{tabular}{|c|c|c|c|}
\hline Position & $\delta_{C}(\text { mult. })^{\mathrm{a}}$ & $\delta_{\mathrm{H}}($ mult., $J$ in $\mathrm{Hz})$ & $\delta_{\mathrm{H}}($ mult., $J$ in $\mathrm{Hz})$ \\
\hline 1 & $63.5 \mathrm{CH}_{2}$ & 4.47 (ddd, $11.9,4.0,3.0^{\circ}$ & 4.35 (ddd, $11.9,5.7,3$. \\
\hline 2 & $71.1 \mathrm{CH}$ & $5.37(\mathrm{~m})$ & - \\
\hline $1 '$ & $127.1(\mathrm{~s})$ & - & - \\
\hline $2^{\prime}$ & $131.4(\mathrm{~d})$ & $7.45(\mathrm{~d}, 8.7)$ & - \\
\hline $3^{\prime}$ & $116.9(\mathrm{~d})$ & $6.79(\mathrm{~d}, 8.7)$ & - \\
\hline $4^{\prime}$ & $161.5(\mathrm{~s})$ & - & - \\
\hline $7^{\prime}$ & $147.3(d)$ & $7.63(d, 15.9)$ & - \\
\hline $8^{\prime}$ & $114.5(\mathrm{~d})$ & $6.34(\mathrm{~d}, 15.9)$ & - \\
\hline $9^{\prime}$ & $168.7(\mathrm{~s})$ & - & - \\
\hline $1 "$ & $127.6(\mathrm{~s})$ & - & - \\
\hline $2 "$ & $115.2(d)$ & $7.04(\mathrm{~d}, 2.1)$ & - \\
\hline $3 "$ & $146.9(s)$ & - & - \\
\hline $4 "$ & $149.8(s)$ & - & - \\
\hline $5 "$ & $116.5(\mathrm{~d})$ & $6.77(\mathrm{~d}, 8.4)$ & - \\
\hline $6 "$ & $123.2(\mathrm{~d})$ & $6.95(\mathrm{dd}, 8.3,2.1)$ & - \\
\hline $7 "$ & $147.7(d)$ & $7.57(\mathrm{~d}, 15.9)$ & - \\
\hline $8 "$ & $114.4(d)$ & $6.27(d, 15.9)$ & - \\
\hline $9 "$ & $168.7(\mathrm{~s})$ & - & - \\
\hline $\mathrm{Ac}$ & - & - & - \\
\hline $\mathrm{CO}$ & $172.0(\mathrm{~s})$ & - & - \\
\hline Me & $20.9(q)$ & $2.08(\mathrm{~s})$ & - \\
\hline
\end{tabular}




\subsubsection{Identification of compound 23}

The ${ }^{1} \mathrm{H}$ and ${ }^{13} \mathrm{C}$ NMR spectra of compound 23 (see table 6) were similar to those obtained for 22. However, two olefinic protons at $\delta_{\mathrm{H}} 7.57(1 \mathrm{H}, \mathrm{d}, J=15.9 \mathrm{~Hz})$ and at $\delta_{\mathrm{H}}$ $6.27(1 \mathrm{H}, \mathrm{d}, J=15.9 \mathrm{~Hz})$ as well as the presence of aromatic rings with three protons as mentioned above for 22 confirmed a symmetric glycerol ester having an acetyl group at C-2 and two caffeoyl groups at C-1 and C-3 as 2-acetyl-1,3-dicaffoylglycerol (Lasiocarpin C) (see figure 5). The spectroscopic data of compound $\mathbf{2 3}$ were in agreement with the values reported in the literature [56].

Table 6: ${ }^{1} \mathrm{H}$ and ${ }^{13} \mathrm{C}$ NMR spectroscopic data for compound 23 in methanol-d4.

\begin{tabular}{cccc}
\hline Position & $\delta_{\mathrm{C}}$ (mult.) $^{\mathrm{a}}$ & $\delta_{\mathrm{H}}$ (mult., J in Hz) & $\delta_{\mathrm{H}}($ mult., $J$ in Hz) \\
\hline 1 & $63.5(\mathrm{t})$ & $4.47(\mathrm{dd}, 12.0,4.0)$ & $4.34(\mathrm{dd}, 12.0,5.8)$ \\
2 & $71.1(\mathrm{~d})$ & $5.37(\mathrm{~m})$ & - \\
$1^{\prime}$ & $127.6(\mathrm{~s})$ & - & - \\
$2^{\prime}$ & $115.3(\mathrm{~d})$ & $7.04(\mathrm{~d}, 1.8)$ & - \\
$3^{\prime}$ & $146.9(\mathrm{~s})$ & - & - \\
$4^{\prime}$ & $149.8(\mathrm{~s})$ & - & - \\
$5^{\prime}$ & $116.5(\mathrm{~d})$ & $6.77(\mathrm{~d}, 8.3)$ & - \\
$6^{\prime}$ & $123.2(\mathrm{~d})$ & $6.95(\mathrm{dd}, 8.3,1.8)$ & - \\
$7^{\prime}$ & $147.7(\mathrm{~d})$ & $7.57(\mathrm{~d}, 15.9)$ & - \\
$8^{\prime}$ & $114.4(\mathrm{~d})$ & $6.27(\mathrm{~d}, 15.9)$ & - \\
$9^{\prime}$ & $168.7(\mathrm{~s})$ & - & - \\
$\mathrm{Ac}$ & - & - & - \\
$\mathrm{CO}$ & $172.0(\mathrm{~s})$ & - & - \\
$\mathrm{Me}$ & $20.9(\mathrm{~d})$ & $2.08(\mathrm{~s})$ & - \\
\hline
\end{tabular}




\subsubsection{Identification of compound 24}

The presence of two non-equivalent $p$-coumarate moieties was detected from the ${ }^{\prime} \mathrm{H}$ NMR spectrum of compound 24. Additionally, this spectrum showed the presence of a 1,2diacylglycerol moiety $\delta_{\mathrm{H}} 5.24(\mathrm{IH}, \mathrm{m}), \delta_{\mathrm{H}} 4.49(1 \mathrm{H}, \mathrm{dd}, J=11.8$ and $3.8 \mathrm{~Hz})$ and $4.35(1 \mathrm{H}$, dd, $J=11.8$ and $6.5 \mathrm{~Hz}$ ) for acylated methylene protons and $\delta_{\mathrm{H}} 3.79(2 \mathrm{H}, \mathrm{m})$ for hydroxymethyl protons (see table 7). Based on the above spectral data, the structure of 24 was determined as 1,2-dicoumaroylglycerol. This was confirmed by ${ }^{13} \mathrm{C} \mathrm{NMR},{ }^{1} \mathrm{H}{ }^{1} \mathrm{H}$ COSY, HMQC and HMBC correlations (see figure 7) and the spectroscopic data of compound $\mathbf{2 4}$ were in agreement with the values reported in the literature [56].

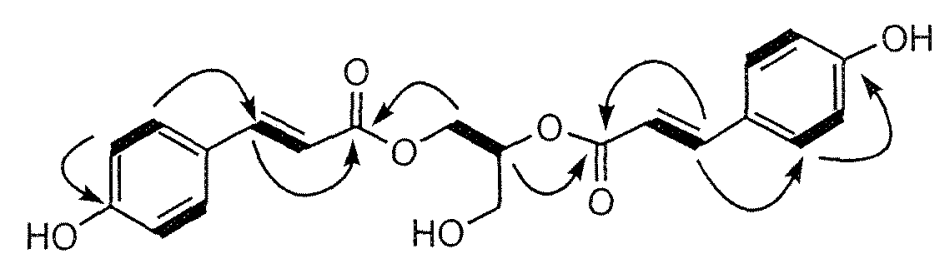

Figure 7: ${ }^{1} \mathrm{H}^{1} \mathrm{H}$ COSY, HMQC and HMBC correlations (24). 
Table 7: ${ }^{1} \mathrm{H}$ and ${ }^{13} \mathrm{C}$ NMR spectroscopic data for compound 24 in methanol-d4.

\begin{tabular}{|c|c|c|c|}
\hline Position & $\delta_{\mathrm{C}}\left(\right.$ mult.) ${ }^{\mathrm{a}}$ & $\delta_{\mathrm{H}}($ mult., $J$ in $\mathrm{Hz})$ & $\delta_{\mathrm{H}}($ mult., $J$ in $\mathrm{Hz})$ \\
\hline 1 & $63.8(t)$ & $4.49(\mathrm{dd}, 11.8,3.8)$ & $4.35(\mathrm{dd}, 11.8,6.5)$ \\
\hline 2 & $73.7(\mathrm{~d})$ & $5.24(\mathrm{~m})$ & - \\
\hline 3 & $61.7(t)$ & $3.79(\mathrm{brd}, 5.1)$ & - \\
\hline 1 & $127.2(\mathrm{~s})$ & - & - \\
\hline $2^{\prime}$ & $131.3(\mathrm{~d})$ & $7.44(\mathrm{~d}, 8.4)$ & $7.04(\mathrm{~d}, 1.8)$ \\
\hline $3^{\prime}$ & $116.9(d)$ & $6.78(\mathrm{~d}, 8.4)$ & - \\
\hline $4^{\prime}$ & $161.4(\mathrm{~s})$ & - & - \\
\hline 7 & $147.1(\mathrm{~d})$ & $7.62(\mathrm{~d}, 15.9)$ & - \\
\hline $8^{\prime}$ & 114.7 (d) & $6.33(\mathrm{~d}, 15.9)$ & - \\
\hline $9^{\prime}$ & $168.9(\mathrm{~s})$ & - & - \\
\hline $1 "$ & $127.1(\mathrm{~s})$ & - & - \\
\hline $2 "$ & $131.3(\mathrm{~d})$ & $7.46(\mathrm{~d}, 8.4)$ & - \\
\hline $3 "$ & $116.9(d)$ & $6.79(\mathrm{~d}, 8.4)$ & - \\
\hline $4 "$ & $161.4(\mathrm{~s})$ & - & - \\
\hline $7^{\prime \prime}$ & $147.1(d)$ & $7.66(d, 15.9)$ & - \\
\hline $8 "$ & $115.0(\mathrm{~d})$ & $6.37(\mathrm{~d}, 15.9)$ & - \\
\hline $9 "$ & $168.7(\mathrm{~s})$ & - & - \\
\hline
\end{tabular}

The next section presents the evaluation of anticancer, anti-inflammatory and antibacterial activities of isolated compounds from Populus tremuloides. 


\subsection{Evaluation of cytotoxicity against human cell lines}

Cytotoxicity of compounds $\mathbf{2 0 - 2 4}$ have been evaluated against human lung cancer (A549), human colorectal cancer (DLD-1) and normal skin fibroblasts (WS1) using resazurin assay as described by O'brien et al. [57]. Resazurin is a non-fluorescent dye reduced to fluorescent resorufin by living cells. The fluorescent is proportional to the quantity of cells. Consequently, this assay allows to determine inhibition of cell growth and cytotoxicity. Resazurin is easy to use as homogeneous assay substrate. It has a fast and robust read-out potential and usability for a wide range of cell types. On the other hand, there are possibilities of interaction with test reagents, spontaneous conversion to fluorescent resafurin and second step conversion of fluorescent resafurin to non-fluorescent metabolites. These disadvantages may cause conflicts in data interpretation [58]. The cytotoxicity was also assessed using Hoescht assay as described by Rago et al. [59], which measure cell DNA quantity, were also carried out to confirm the results of the resazurin tests. Hoechst stains are part of a family of fluorescent stains for labelling DNA It provides a linear relationship between fluorescence and DNA content over a broad range of DNA. This reaction is DNA-specific and does not work with other cellular components such as RNA, protein, or carbohydrate. This enables the rapid and accurate measurement of cell number involving minimal processing time, making this assay well suited for cell proliferation studies[60]. The results presented in table 8 are expressed as the concentration of compound inhibiting cell growth by $50 \%\left(\mathrm{IC}_{50}\right)$. The etoposide was used as positive control, exhibited $\mathrm{IC}_{50}$ of $3.4 \pm 0.1,27 \pm 5$ and $34 \pm 4 \mu \mathrm{M}$ against A549, DLD-1 and WS1 
respectively for the resazurin test as well as $2.8 \pm 0.5,2 \pm 1$ and $>50 \mu \mathrm{M}$ for Hoechst assay.

Compound $\mathbf{2 3}$, never previously reported for anticancer activity, exhibited a significant cytoxicity against $\mathrm{A} 549$ and DLD-1 with $\mathrm{IC}_{50}$ of 9 and $20 \mu \mathrm{M}$ respectively for the resazurin tests. Hoechst assays $\mathrm{IC}_{50}$ values were 9 and $12.8 \mu \mathrm{M}$. However, compound 23 was not selective towards cancer cell lines. $\mathrm{IC}_{50}$ values of compound $\mathbf{2 1}$ indicated that this molecule was weakly active on A549 and DLD-1 using both cytotoxic assays, whereas compounds 20,22 and 24 were found to be inactive $\left(\mathrm{IC}_{50}>100 \mu \mathrm{M}\right)$ against all cell lines tested.

Table 8: In vitro cytotoxicity results of phenolic compounds.

\begin{tabular}{|c|c|c|c|c|c|c|}
\hline \multirow[b]{3}{*}{ Compounds } & \multicolumn{6}{|c|}{$\mathrm{IC}_{50}(\mu \mathrm{M})^{\mathrm{a}}$} \\
\hline & \multicolumn{3}{|c|}{ Resazurin } & \multicolumn{3}{|c|}{ Hoechst } \\
\hline & $\mathrm{A}-549^{\mathrm{b}}$ & DLD- $1^{c}$ & $\mathrm{WS}^{\mathrm{d}}$ & A-549 & $\overline{\text { DLD-1 }}$ & WS1 \\
\hline 20 & $>100$ & $>100$ & $>100$ & $81 \pm 2$ & $>100$ & $>100$ \\
\hline 21 & $49 \pm 6$ & $75 \pm 5$ & $60 \pm 3$ & $32 \pm 4$ & $42 \pm 5$ & $55 \pm 4$ \\
\hline 22 & $>100$ & $>100$ & $>100$ & $45 \pm 2$ & $43 \pm 6$ & $77 \pm 2$ \\
\hline 23 & $9 \pm 1$ & $20 \pm 1$ & $10 \pm 1$ & $9 \pm 1$ & $12.8 \pm 1$ & $14 \pm 7$ \\
\hline 24 & $>100$ & $>100$ & $>100$ & $>100$ & $>100$ & $>100$ \\
\hline Etopside $^{e}$ & $3.4 \pm 0.1$ & $27 \pm 5$ & $34 \pm 4$ & $2.8 \pm 0.5$ & $2 \pm 1$ & $>50$ \\
\hline
\end{tabular}

${ }^{a} \mathrm{IC}_{50}$ value of extract which was defined as a concentration that caused $50 \%$ inhibition of cell proliferation.

${ }^{\mathrm{b}}$ Human lung carcinoma

${ }^{\mathrm{c}}$ Human colorectal adenocarcinoma

${ }^{\mathrm{d}}$ Human normal skin fibroblasts

${ }^{\mathrm{e}}$ positive control. 


\subsection{Evaluation of the anti-inflammatory activity of isolated compounds on LPS activated RAW 264.7 macrophages}

Exponentially growing cells were plated in 24-well microplates (BD Falcon) at a densisty of $2 \times 10^{5}$ cells per well in $400 \mu$ l of culure medium and were allowed to adhere overnight. Cells were then treated or not with positive control $N(G)$-nitro-L-arginine methyl ester (L-NAME), or growing concentrations of pure compounds dissolved in the appropriate solvents, and incubated at $37^{\circ} \mathrm{C}, 5 \% \mathrm{CO}_{2}$ for $24 \mathrm{~h}$. The final concentration of solvent in the culture medium was maintained at $0.5 \%(\mathrm{v} / \mathrm{v})$ to avoid solvent toxicity. Cells were then stimulated with $10 \mu \mathrm{g} \cdot \mathrm{ml}^{-1}$ lipopolysaccharide (LPS). After 24h, cell-free supernatants were collected and stored at $-80^{\circ} \mathrm{C}$ until NO determination using the Greiss reaction [61] with $1 \%$ sulphanilamide and $50 \mu \mathrm{l}$ of $0.1 \% \mathrm{~N}-1$-naphtylethylenediamine dihydrochloride in $2.5 \% \mathrm{H}_{3} \mathrm{PO}_{4}$ at room temperature for 20 min. Absorbance at $540 \mathrm{~nm}$ was then measured using an automated 96-well Varioskan Ascent plate reader (Thermo Electron) and the presence of nitrite was quantified by comparison with an $\mathrm{NaNO}_{2}$ standard curve. All the samples were tested at the highest concentration which presents no cytotoxicity. Anti-inflammatory activity was expressed as the concentration of drug inhibiting nitric oxide overproduction by $50 \%$ (IC50).

The anti-inflammatory activity of phenolic triglyceride component $\mathbf{2 1}$ has been reported to be beneficial in the treatment of chronic inflammatory diseases [62] which prompted us to examine the activity of similar compounds. In the inflammation process, nitric oxide (NO) is related to inflammatory reaction and is produced from L-arginine by the inducible 
NO synthase (iNOS) in certain cells activated by various pro-inflammatory agents like lipopolysaccharide (LPS). Although NO acts as a host defense, it contributes to tissue injury in inflammatory diseases [63]. Thus, effective inhibition of NO gathering by inflammatory stimuli represents a beneficial therapeutic strategy.

Anti-inflammatory activity was evaluated using NO inhibition on LPS-activated RAW 264.7 macrophages. NO released from cells is detected and quantified. L-NAME, a NO synthase inhibitor, prevented the formation of NO in LPS-stimulated RAW 264.7 macrophages [64] and as used as positive control. Resazurin test was also made to ensure that the reduced production of NO is not related to cytotoxicity. The resazurin assay was performed with growing concentrations of the extracts ranging from 0 to $40 \mu \mathrm{M}$.

The result presented in table 9 show that the compounds 21,23 , and 24 were found cytotoxic against RAW 264.7 macrophages. Therefore, it is not possible to determine $\mathrm{IC}_{50}$ for these compounds. In contrast the compound $\mathbf{2 0}$ and $\mathbf{2 2}$ are not cytotoxic for macrophages. The compound 20 weakly inhibit NO overexpression induced by LPS with an $\mathrm{IC}_{50}$ of $62 \mu \mathrm{M}$. Interestingly, the compound 22 demonstrates a strong inhibition of NO production with an $\mathrm{IC}_{50}$ of $6.5 \mu \mathrm{M}$. In comparison, the $\mathrm{IC}_{50}$ of positive control L-NAME is about $1 \mathrm{mM}$. 
Table 9: NO Inhibition induced by phenolic compounds on LPS-activated RAW 264.7 macrophages.

\begin{tabular}{cc}
\hline Compounds & $\mathrm{IC}_{50}(\mu \mathrm{M})^{\mathrm{a}}$ \\
\hline $\mathbf{2 0}$ & $62 \pm 30^{\mathrm{b}}$ \\
$\mathbf{2 1}$ & $\mathrm{ND}^{\mathrm{c}}$ \\
$\mathbf{2 2}$ & $6.5 \pm 0.4$ \\
23 & $\mathrm{ND}^{\mathrm{c}}$ \\
$\mathbf{2 4}$ & $\mathrm{ND}^{\mathrm{c}}$ \\
\hline
\end{tabular}

${ }^{\mathrm{a}} \mathrm{IC}_{50}$ value of extract which was defined as a concentration that caused $50 \%$ inhibition of cell proliferation.

${ }^{b}$ Data represent the mean \pm standard deviation of three independent experiments.

${ }^{\mathrm{c}} \mathrm{ND}$ : not determined due to macrophage cytotoxicity.

\subsection{Evaluation of antibacterial activity of compounds isolated from Populus tremuloides.}

The antibacterial activity of compounds $\mathbf{2 0 - 2 3}$ was tested against two bacteria strains including gram-positive Staphylococcus aureus (ATCC 25923) and gram-negative Escherichia coli (ATCC 25922). The $S$. aureus and E. coli bacteria are implicated in various pathologies and often responsible for infections contracted in hospitals (nosocomial infections) $[65,66]$. The results are expressed as $\mathrm{IC}_{50}(\mu \mathrm{M})$ (table 10). Chloramphenicol was used as positive control in this antibacterial assay with $\mathrm{IC}_{50}$ of $>5 \mu \mathrm{M}$ for S.aureus and $0.37 \pm 0.06 \mu \mathrm{M}$ for E.coli. The results presented in table 10 show that compound 20 and 23 was inactive against S.aureus whereas compound $\mathbf{2 1}$ and 22 was found weakly active with 
$\mathrm{IC}_{50}$ of 34 and $59 \mu \mathrm{M}$, respectively. Interestingly, the compound 22 and 23 demonstrated significant antibacterial activity against E.coli with $\mathrm{IC}_{50}$ of 25 and $16 \mu \mathrm{M}$, respectively.

Table 10: Antibacterial activity of phenolic compounds against $S$. aureus and E. coli.

\begin{tabular}{lcc}
\hline \multirow{2}{*}{ Compounds } & \multicolumn{2}{c}{ IC $_{50}(\mu \mathrm{M})^{\mathrm{a}}$} \\
\cline { 2 - 3 } & S.aureus $^{\mathrm{E}}$ & E.coli \\
\hline 21 & Inactive $^{\mathrm{c}}$ & Inactive $^{\mathrm{c}}$ \\
22 & $34 \pm 4^{\mathrm{b}}$ & Inactive $^{\mathrm{c}}$ \\
$\mathbf{2 3}$ & $59 \pm 5^{\mathrm{b}}$ & $25 \pm 2^{\mathrm{b}}$ \\
Chloramphenicol $^{\mathrm{d}}$ & Inactive $^{\mathrm{c}}$ & $16 \pm 3^{\mathrm{b}}$ \\
\hline
\end{tabular}

${ }^{\mathrm{a}} \mathrm{IC}_{50}$ : concentration of compound inhibiting fifty percent of bacterial proliferation.

${ }^{\mathrm{b}}$ Data represent the mean \pm standard deviation of three independent experiments.

${ }^{c}$ Pure compound was considered inactive when $\mathrm{IC}_{50}>100 \mu \mathrm{M}$.

${ }^{\mathrm{d}}$ positive control. 
Chapter VI

CONCLUDING REMARKS AND FUTURE DIRECTIONS 
Very few investigations have been carried out on bioactive constituents of $P$. tremuloides which were commonly used by Amerindian traditional medicine to treat numerous diseases. Some new information about chemical constituent of buds of $P$. tremuloides:

- The fraction $\mathrm{C}$ from $n$-BuOH extract showed an important cytotoxic activity against A549 and DLD-1 cell lines.

- Bioassay-guided fractionation of this fraction with a combination of different chromatographic techniques led to the isolation of 24 phenolic compounds, namely: $(1 S, 2 S)$-1-[4-O-(E)-coumaroyl- $\beta$-D-glucopyranosyloxy] cyclohexane-diol (1), chaenomeloidin (2), prunin (3), echinaticin (4), echinacin (5), tremulacin (6), salicine (7), tremuloidin (8), genkwanin (9), rhamnocitrin (10), sakuranetin (11), acacetin (12), kaempferide (13), aromadendrin (14), phenylmethyl coumarate (15), phenethyl p-coumarate (16), cinnamyl coumarate (17), phenylmethyl caffeate (18), trans-ferulic acid (19), 1,3-0-di-trans-p-coumaroylglycerol (20), Lasiocarpin A (21), Lasiocarpin B (22), Lasiocarpin C (23) and 1,2-dicoumaroylglycerol (24).

- Compound 1 is a new molecule and was not reported in literature before.

- Compounds $\mathbf{2 0}$ and $\mathbf{2 4}$ were not reported before for Salicaceae family.

- Compounds 2 and 5 were not reported before for Populus genus.

- Compounds $3,4,9,10,12,16,17,21,22$ and 23 were identified for the first time in $P$. tremuloides. 
- Compounds 9, 12, 15, 18 and 23 exhibited significant inhibitory activities against A549 and DLD-1 cells with $\mathrm{IC}_{50}$ values comprised between 8 and $24 \mu \mathrm{M}$.

- It was found, for the first time, that compounds $\mathbf{1 5}$ and $\mathbf{2 3}$ had anticancer activities.

- Compound 22 exhibited high anti-inflammatory potency towards RAW 264.7 cells.

- Complete ${ }^{1} \mathrm{H},{ }^{13} \mathrm{C}$ NMR spectroscopic data were performed for compound 15 and ${ }^{13} \mathrm{C}$ NMR spectroscopic data for compounds 22,23 and 24 . These data were not reported before.

For future studies, it would be valuable to evaluate the chemical structures and the corresponding biological activities of molecules in the bark, resin and root of $P$. tremuloides or other species of Populus of the boreal forest. Our experiment showed (TLC) that there were some differences in the materials of bark and resin of $P$. tremuloides. In addition, they are suggested to be effective in traditional medicine [9]. It would be interesting to investigate the synergic effects of isolated molecules for different biological activities.

It is certainly important to synthetize higher quantities of the bioactive molecules found in this research to test their other aspects in short and long term. Ultimately, in vivo studies on most active molecules are essential. 


\section{Chapter VI REFERENCES}


[1] Phillipson, J. D., 2001. Pythochemistry and medicinal plants. Phytochemistry. 56, 237-243.

[2]. World Health Organization, 2002. Traditional and Alternative Medicine, Fact Sheet \# 271. World Health Organization, Geneva.

[3]. Balunas, M. J., Kinghorn, A.D., 2005. Drug discovery from medicinal plants. Life Sciences 78, 431-441.

[4]. Rollinger, J. M., Haupt, S., Stuppner, H., Langer T.J., 2004. Combining Ethnopharmacology and Virtual Screening for Lead Structure Discovery: COXInhibitors as Application Example. Chem. Inf. Comput. Sci., 44, 480-488.

[5]. Newman, D. J., Cragg, G. M., Snader, K. M., 2003. Natural products as sources of new drugs over the period 1981-2002. J. Nat. Prod. 66 (7), 1022-1037.

[6]. Cragg, G. M., Kingston, D. G. I., Newman, D. J., 2005. Anticancer agents from natural products. CRC Press, Taylor \& Francis Group, Boca Raton, FL.

[7]. Cutler, S. J., Cutler, H. G., 2000. Biologically Active Natural Products: Pharmaceuticals. CRC Press, New-York, pp.277.

[8]. Balandrin, M. F., Kinghorn, A. D., Famsworth, N. R., 1993. Human medicinal agents from plants. Kinghorn, A.D., Balandrin, M.F., Eds.: ACS Symposium Series 534, American Chemical Society, Washington, D.C, 2-12.

[9]. Moermann, D. E., 1998. Native American ethnobotany. Timbre Press, Portland, OR.

[10]. Black, M. J., 1980. Algonquin ethnobotany: an interpretation of aboriginal adaptation in southwestern Quebec, National Museum of Canada.

[11]. Legault, J., Dahl, W., Debiton, E., Pichette, A., Madelmont, J. C., 2003. Antitumor activity of balsam fir oil: Production of reactive oxygen species induced by $\alpha$ humulene as possible mechanism of action. Planta Med. 69, 402-407.

[12]. Russell, M. B., Honkala, B. H. tech.co-ords. 1990, Silvics of North America: 2.Hardwoods. Agriculture Handbook, 654. U.S. Forest service, Washington, DC. vol 2, 877p.

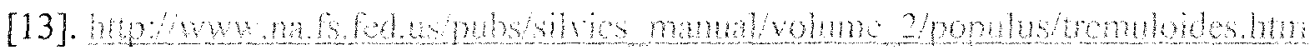


[14]. Grieve, A. Modern Herbal. Penguin 1984 ISBN 0-14-046-440-9.

[15]. Usher, G. A Dictionary of Plants Used by Man. Constable 1974 ISBN 0094579202.

[16]. Weiner. M. A. Earth Medicine, Earth Food. Ballantine Books 1980 ISBN 0-44990589-6.

[17]. Bown, D. Encyclopaedia of herbs and their uses. Dorling Kindersley, London. 1995 ISBN 0-7513-020-31.

[18]. Foster, S., Duke, J, A. A Field guide to medicinal plants. Eastern and central N. America. Houghton Mifflin Co., 1990 ISBN 0395467225.

[19].Wyk, V., Erik, B., Wink, M., 2004. Medicinal plants of the world. Portland, Or. : Timber Press, $480 \mathrm{p}$.

[20]. Britt, K.W., 1970. Handbook of Pulp and Paper Technology 2nd ed. (Britt, K. W., ed.) p. 61. Van Nostrand Reinhold, New York.

[21]. Palo, R. T., 1984. Distribution of birch (Betula spp.), willow (Salix spp.), and poplar (Populus spp.) secondary metabolites and their potential role as chemical defense against herbivores. J. Chem. Ecol. 10, 499-520.

[22]. Lindroth, R. L., Hwang, S. Y., 1996. Diversity, redundancy, and multiplicity in chemical defense of aspen. Recent Adv. Phytochem. 30, 25-56.

[23]. Christov, R., Trusheva, B.; Popova, B., Bankova, V., Bertrand, M., 2006. Nat. Prod. Res. 20, 531-536.

[24]. Ghisalberti, E. L., 1979 Propolis: A Review. Bee WId. 60, 59-84.

[25]. De Campos, R. O., Paulino, N., Da Silva, C. H., Scremin, A., Calixto, J. B., 1998. Antihiperalgesic effect of $\mathrm{Na}$ ethanolic extract of propolis on mice and rats. $\mathrm{J}$. Pharm. Pharmacol. 50, 1187-1193.

[26]. Van Hoff, L., Totté, J., Corthout, J., Pieters, L. A., Mertens, F., Vanden Berghe, D. A., Vlietinck, A. J., 1989. Plant antiviral agents, VI., isolation of antiviral phenolic glycosides from Populus cultivar Beaupre by droplet counter-current chromatography. J. Nat. Prod. 52, 875-878.

[27]. Mattes, B. R., Clausen, T. P., Reichardt, P. B., 1987. Volatile Constituents of Balsam Poplar: The Phenol Glycoside Connection. Phytochemistry. 26, 1361-1366. 
[28]. Jerkovic, I., MAstelic, J., 2003. Volatile compounds from leaf-buds of Populus nigra L. (Salicaceae). Phytochemistry, 63, 109-113.

[29]. English, S., Greenaway, W., Whatley, F. R., 1991. Bud exudate composition of Populus tremuloides. Can. J. Bot. 69, 2291-2295.

[30]. Greenaway, W., Scaysbrook, T., Whatley, F. R., 1987. The analysis of bud exudate of Populus euramericana, and of propolis, by gas chromatography-mass spectrometry. Proc. R. Soc. Lond. B 232, 249-272.

[31]. Nagy, E., Papay, Y., Litkei, G. Y., Dinya, Z., 1986. Proc. 7th Hungarian Bioflavonoid Symposium, Szeged, Hungary. Studies in organic chemistry 23, (Farkas, L. et al., eds), p. 223, Elsevier, Amsterdam.

[32]. Wollenweber, E., 1975. Flavonoidmuster als systematisches merkmal in der Gattung Populus. Biochem. Syst. Ecol. 3, 35-45.

[33]. Scaysbrook, T., Greenaway, W., Whatley, F. R., 1992. Relation of "antimicrobial" compounds present in poplar bud exudates to disease resistance by poplars. Z. Naturforsch. $47 \mathrm{c}, 197-200$.

[34]. Greenaway, W., Whatley, F. R., 1991. Synthesis of esters of acetyloxycaffeic acids and their occurrence in poplar bud exudates. J. Chromatogr. 543, 113-121.

[35]. Greenaway, W., English, S., May, J., Whatley, F. R., 1992a. Analysis of phenolics of bud exudates of Populus koreana, Populus maximowiczii and Populus suaveolens by GC-MS. Z. Naturforsch. 47c, 313-317.

[36]. Greenaway, W., English, S., May, J., Whatley, F. R. 1992b. Analysis of phenolics of bud exudates of Populus cathayana and Populus szechuanica by GC-MS. Z. Naturforsch. 47c, 308-312.

[37]. English, S., Greenaway, W., Whatley, F. R., 1992. Analysis of phenolics of bud exudates of Populus tristis by GC-MS. Z. Naturforsch. 47c, 512-515.

[38]. Maciejewicz, W., Daniewski, M., Dzido, T. H., Bal, K., 2002. GC-MS and HPLC analysis of phenolic acids extracted from propolis and from Populus nigra bud exudate. Chern. Anal. 47, 21-30.

[39]. Greenaway, W., English, S., May, J., Whatley, F. R., 1991. Chemotaxonomy of section Leuce poplars by GC-MS of bud exudates. Biochem. Syst. Ecol. 19, $507-$ 518. 
[40]. Greenaway, W., English, S., Whatley, F. R., 1990. Phenolic composition of bud exudates of Populus deltoids. Z. Naturforsch. 45c, 587- 593.

[41]. Greenaway, W., English, S., Whatley, F. R., 1990. Variations in bud exudates composition of Populus nigra assessed by gas chromatography-mass spectrometry. Z. Naturforsch. 45c, 931-936.

[42]. Greenaway, W., May, J., Whatley, F. R., 1989. Flavonoid aglycones identified by gas chromatography-mass spectrometry in bud exudate of Populus balsamifera. J. Chromatogr. 472, 393-400.

[43]. Shain, L. and Miller, J. B., 1982. Pinocembrin: an antifungal compound secreted by leaf glands of eastern cottonwood. Phytopathology 72, 877-880.

[44]. Charriere-Ladreix,Y., 1973. Etude de la secretion flavonoidique des bourgeons de Populus nigra L. var. italica: Cinetique du phenomene secretoire; ultrastructure et evolution des tissu glandulaire. J. Microscopie 17, 299-316.

[45]. Bankova, V., Dyulgerov, A. I., Popov, S., Marekov, N., 1987. A GC/MS study of the propolis phenolic constituents. Z. Naturforsch. 42c, 147-151.

[46]. Aga, H., Shibuya, T., Sugimoto, T., Kurimoto, M., Nakajima, S., 1994. Isolation and Identification of antimicrobial compounds in Brazilian propolis. Biosci. Biotech. Biochem., 58 (5), 945-946.

[47]. Scaysbrook, T., Greenaway, W., Whatley, F. R., 1992. Relation of" antimicrobial" compounds present in poplar bud exudate to disease resistance by poplars. $Z$. Naturforsch. 47c, 197-201.

[48]. Warnant, P., Mertens, P., Marche, C., 2004. Screening of poplar biomass for bioactive compounds: a simple method to assess antioxidant activity. Bioresour. Technol. 93, 43-48.

[49]. Chiristov, R., Trusheva, B., Popova, M., Bankova, V., Bertrand, M., 2005. Chemical composition of propolis from Canada, its antiradical activity and plant origin. Nat. Prod. Res. 19 (7), 673-678.

[50]. Fernandez, M. P., Watson, P. A., Breuil, C., 2001. Gas chromatography-mass spectrometry method for the simultaneous determination of wood extractive compounds in quaking aspen. J. Chromatogr. A. 922, 225-233.

[51]. Abramovitch, R. A., Micetic, R. G., 1963. Extraactives from Populus tremuloides heartwood the triterpene alcohols. Can. J. Chem. 41, 2362-2367. 
[52]. Pearl, I. A., Darling, S. F., Justman, O., 1962. Studies on the Leaves of the family salicaceae. I. Populin from the Leaves Populus grandidentata and Populus tremuloides. J. Org. Chem. 27, 2685-2687.

[53]. Pearl, I. A., Darling, S.F., 1959. Studies on the Barks of the Family salicaceae. II. Salireposide from the Bark of Populus tremuloides. J. Org. Chem. 24, 1616.

[54]. Lindroth, R. L., Hwang, S.Y., 1996. Diversity, redundancy, and multiplicity in chemical defense of aspen. Recent. Adv. Phytochem. 30, 25-56.

[55]. Koshino, H., Terada, S-. I., Yoshihara, T., Sakamura, S., Shimanuki, T., Sato, T., Tajimi, A., 1988. Three phenolic acid derivatives from stromata of Epichloe typhina on Phleum pratense. Phytochemistry. 27 (5), 1333-1338.

[56]. Asakawa, Y., Takemoto, T., Wollenweber, E., Aratani, T., 1977. Lasiocarpin A, B and $\mathrm{C}$, three novel phenolic triglycerides from Populus lasiocarpa. Phytochemistry. $16,1791-1795$.

[57]. O'Brien, J., Wilson, I., Orton, T., Pognan, F., 2000. Investigation of the Alamar Blue (resazurin) fluorescent dye for the assessment of mammalian cell cytotoxicity. Eur. J. Biochem. 267, 5421-5426.

[58]. Tech Note 52, Comparison of bottom materials in cell based assays. wwwnunc de

[59]. Rago, R., Mitchen, J., Wilding, G., 1990. DNA fluorometric assay in 96-well tissue culture plates using Hoechst 33258 after cell lysis by freezing in distilled water. Anal. Biochem. 191, 31-34.

[60]. Hawley, R. C; Teresa, S., 2004. Flow Cytometry Protocols (Methods in Molecular Biology (Clifton, N.J.), V. 263.). Totowa, NJ: Humana Press. ISBN 1-58829-235-5.

[61]. Green, S. J., Meltzer, M. S., Hibbs, J. B., Nacy, C. A., 1990. Activated macrophages destroy intracellular Leishmania major amastigotes by an L-arginine-dependant killing mechanism. The Journal of Immunology. 144, 278-283.

[62]. Nagaoka, T., Banskota, A. H., Tezuka, Y., Midorikawa, K., Matsushige, K., Kadota, S., 2003. Caffeic acid phenethyl ester (CAPE) analogues: potent nitric oxide inhibitors from the netherlands propolis .Biol. Pharm. Bull. 26(4), 487-491.

[63]. Szabo, C., 2003. Multiple pathways of peroxynitrite cytotoxicity. Toxicol. Lett. 140-141, 105-112. 
[64]. Paul, A., Bryant, C., Lawson, M. F., Chilvers, E. R., Plevin, R., 1997. Dissociation of lipopolysaccharide-mediated induction of nitric oxide synthase and inhibition of DNA synthesis in RAW 264.7 macrophages and rat aortic smooth muscle cells. Br. J. Pharmacol. 120, 1439-1444.

[65]. Branger, B., 2005. National survey of nosocomial infection prevalence among newborns and under-eighteen children and adolscets in France. Arch Pediatr. 12, $1085-1093$.

[66]. Fritsche, T. R., Sader, H. S., Stilwell, M. G., Dowzicky, M. J., Jones, R. N., 2005. Antimicrobial activity of tigecycline tested against organisms causing communityacquired respiratory tract infection and nosocomial pneumonia. Diagn. Microbio. Infect. Dis. 52, 187-193. 


\section{APPENDIX}

\section{NMR Spectra}


${ }^{1} \mathrm{H}$ of compound (1)

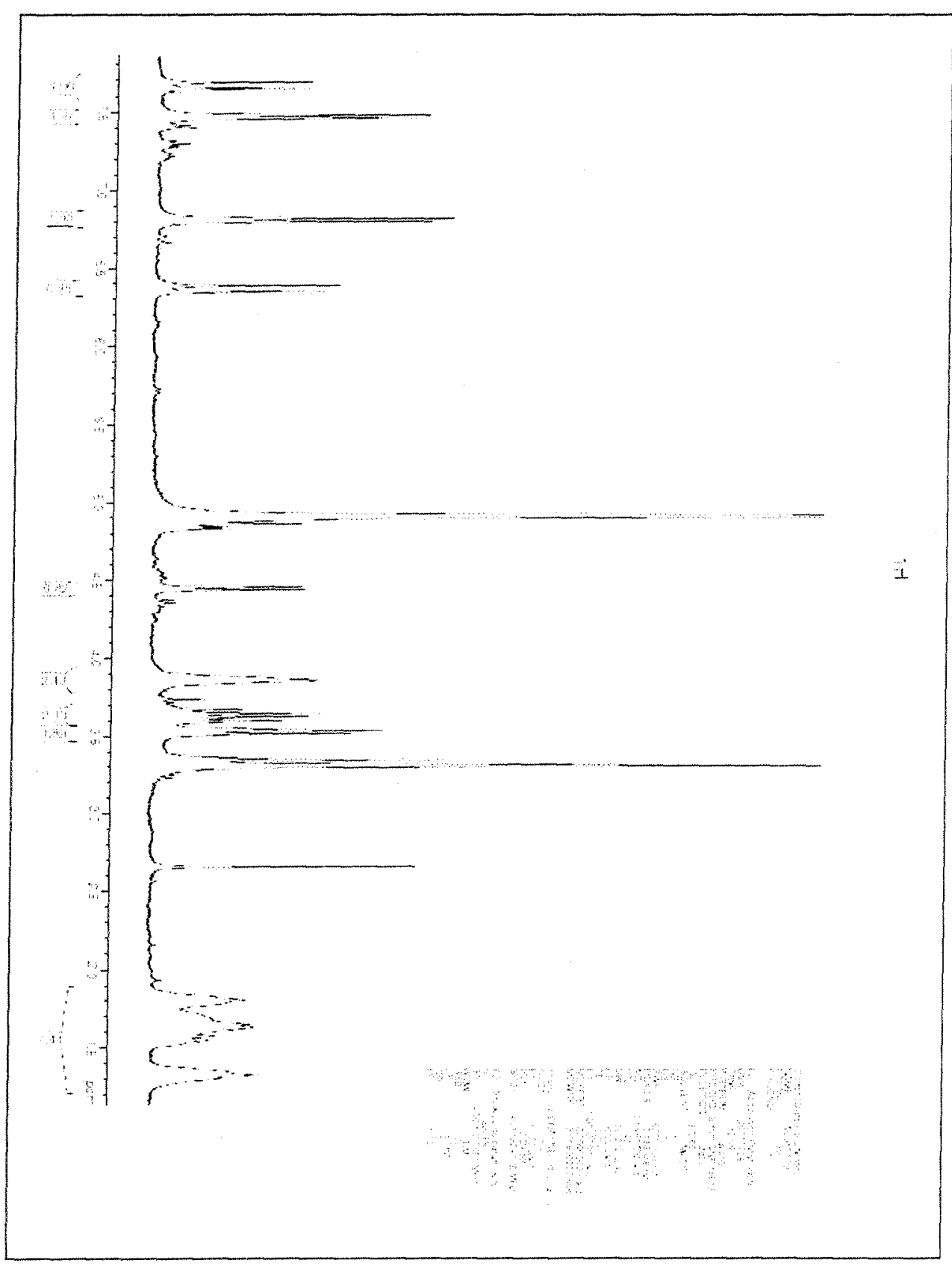


66

${ }^{13} \mathrm{C}$ of compound (1)

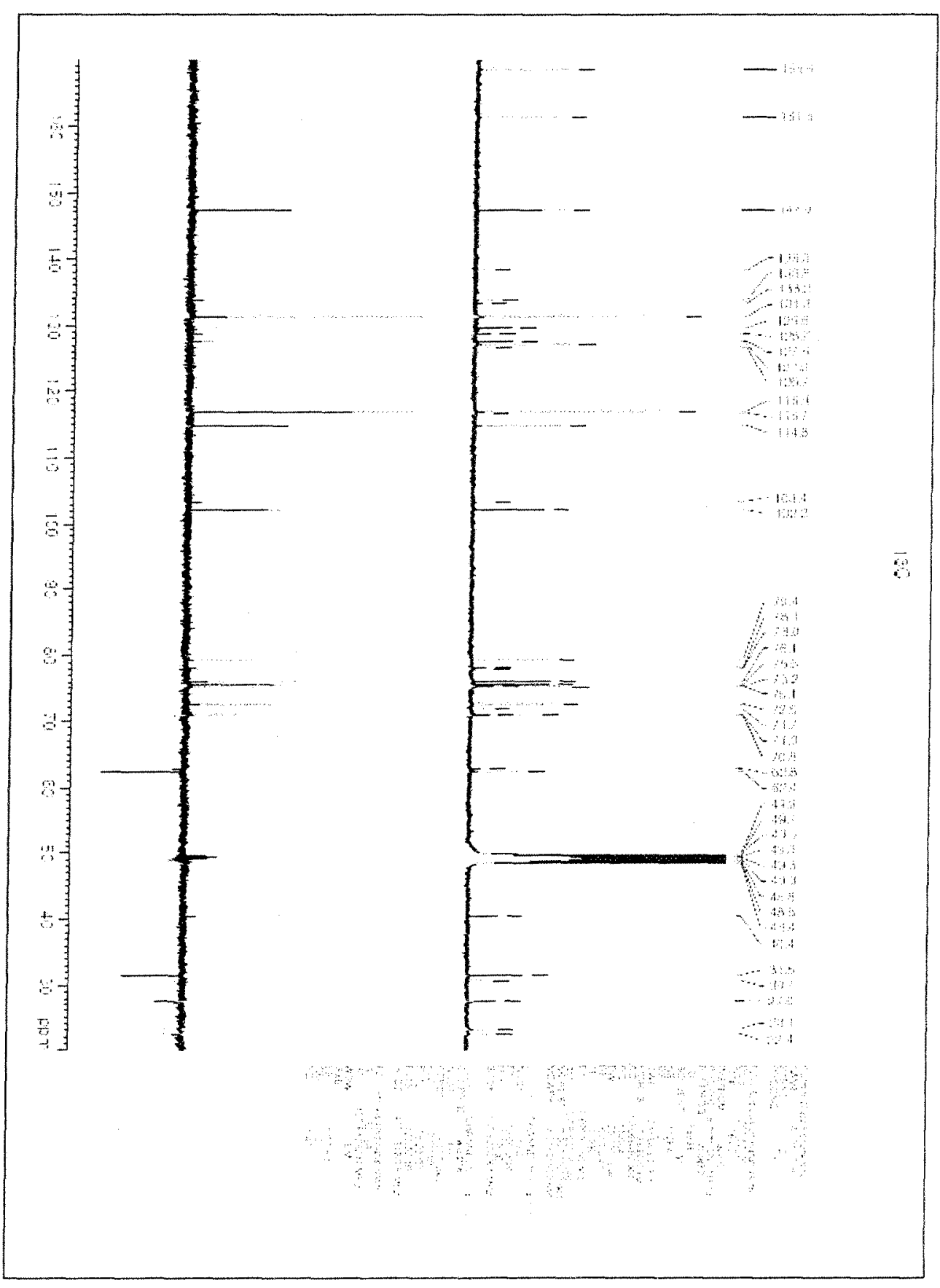


${ }^{1} \mathrm{H}$ of compound (15)

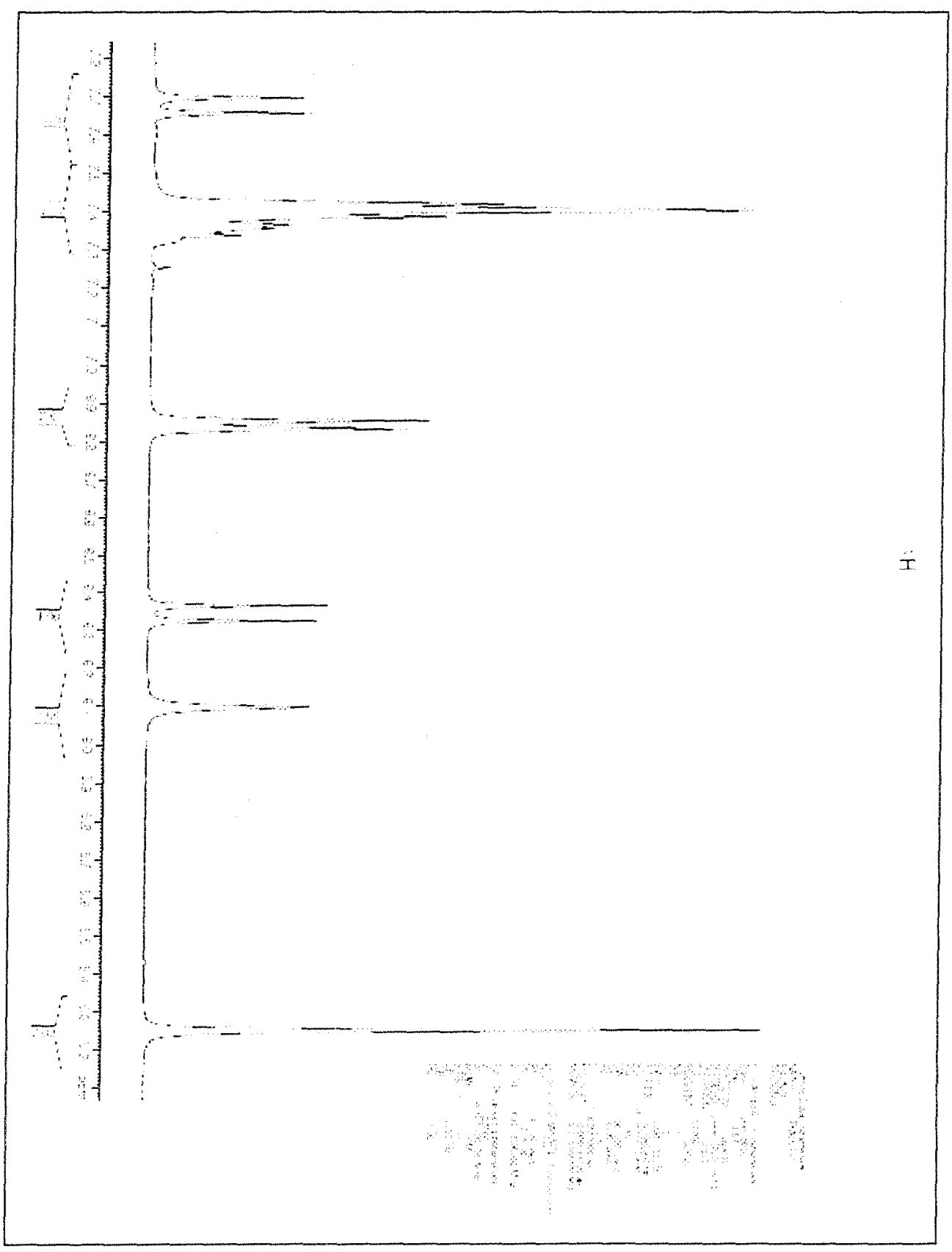


${ }^{13} \mathrm{C}$ of compound (15)

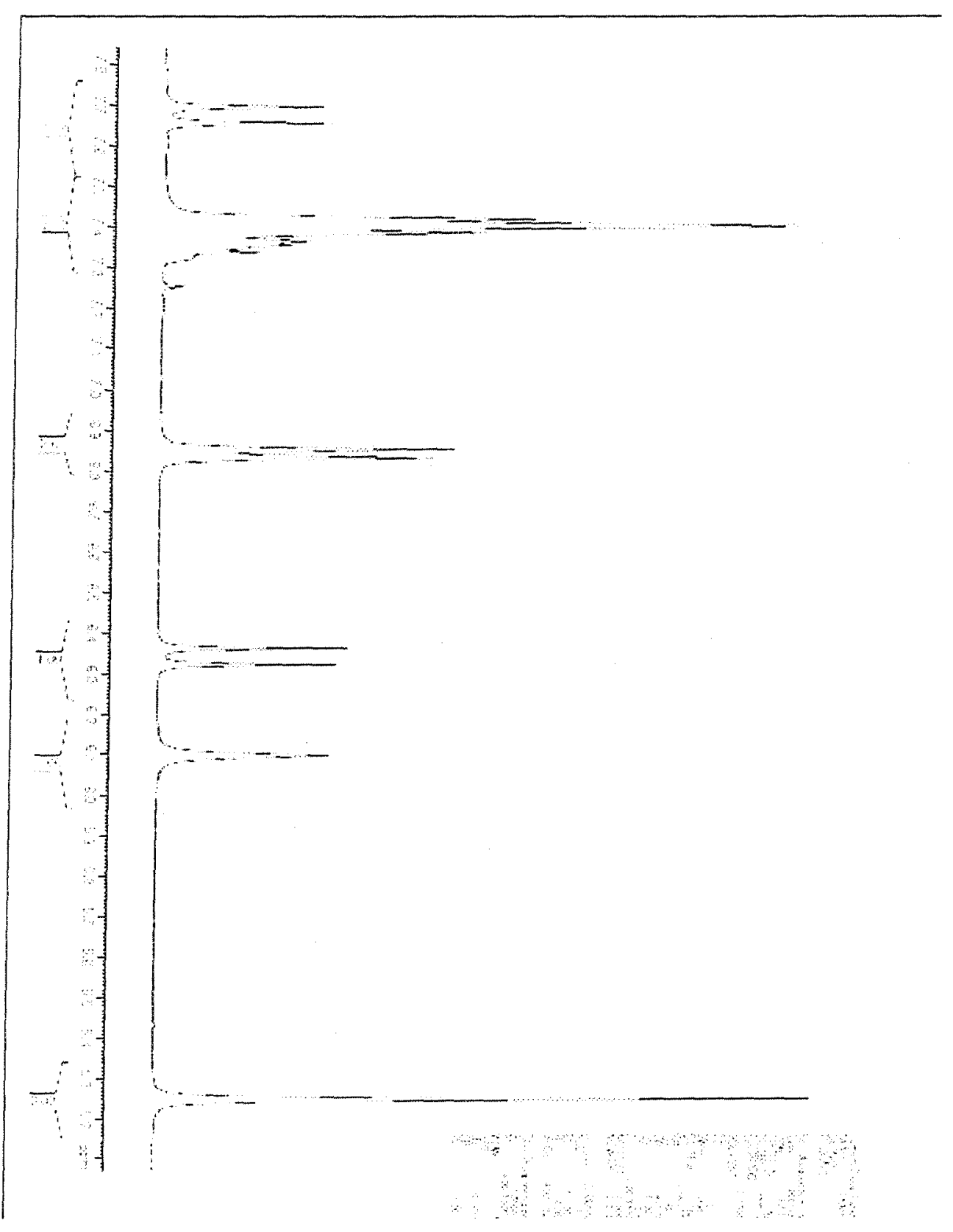


69

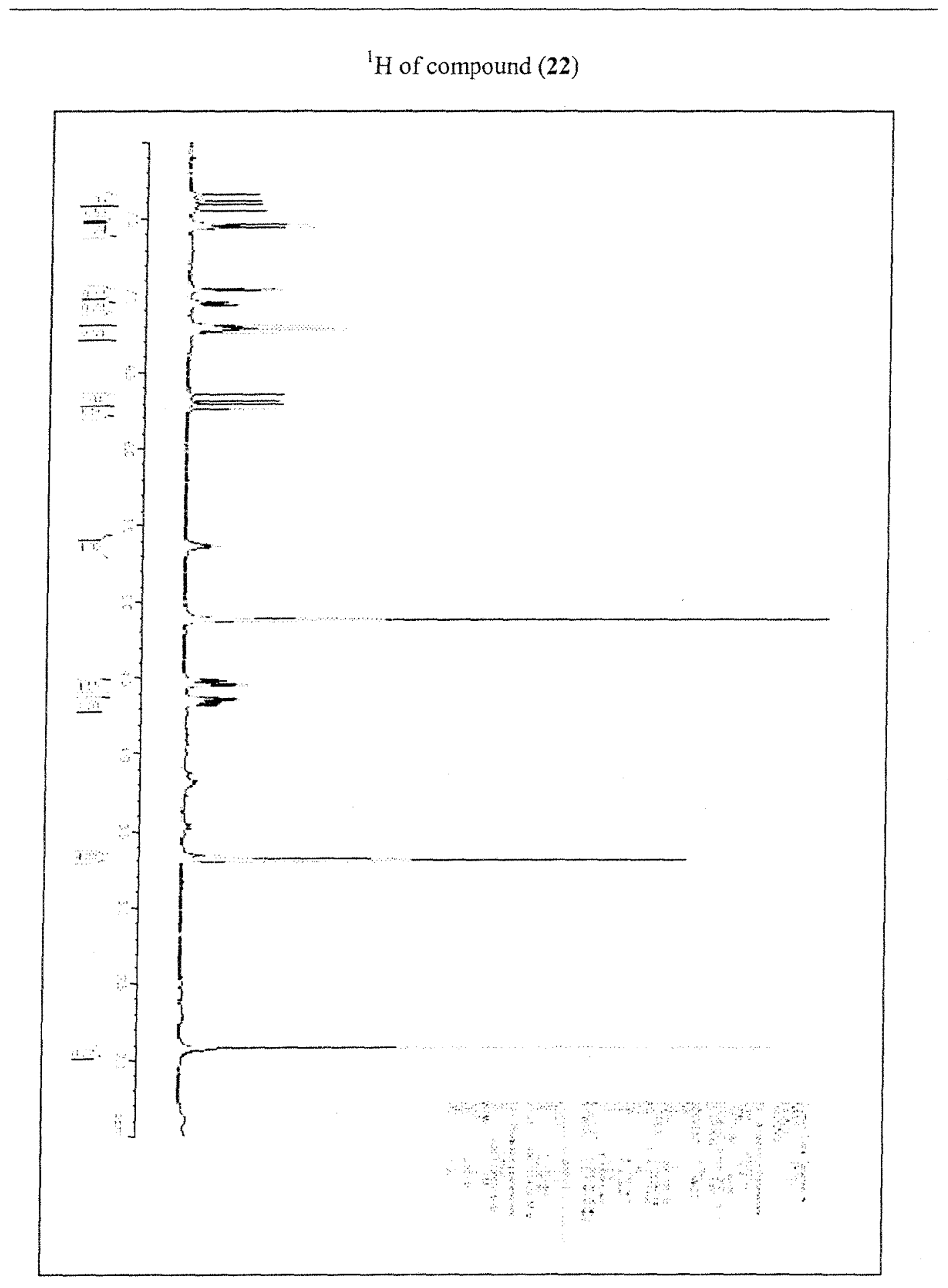


${ }^{13} \mathrm{C}$ of compound (22)

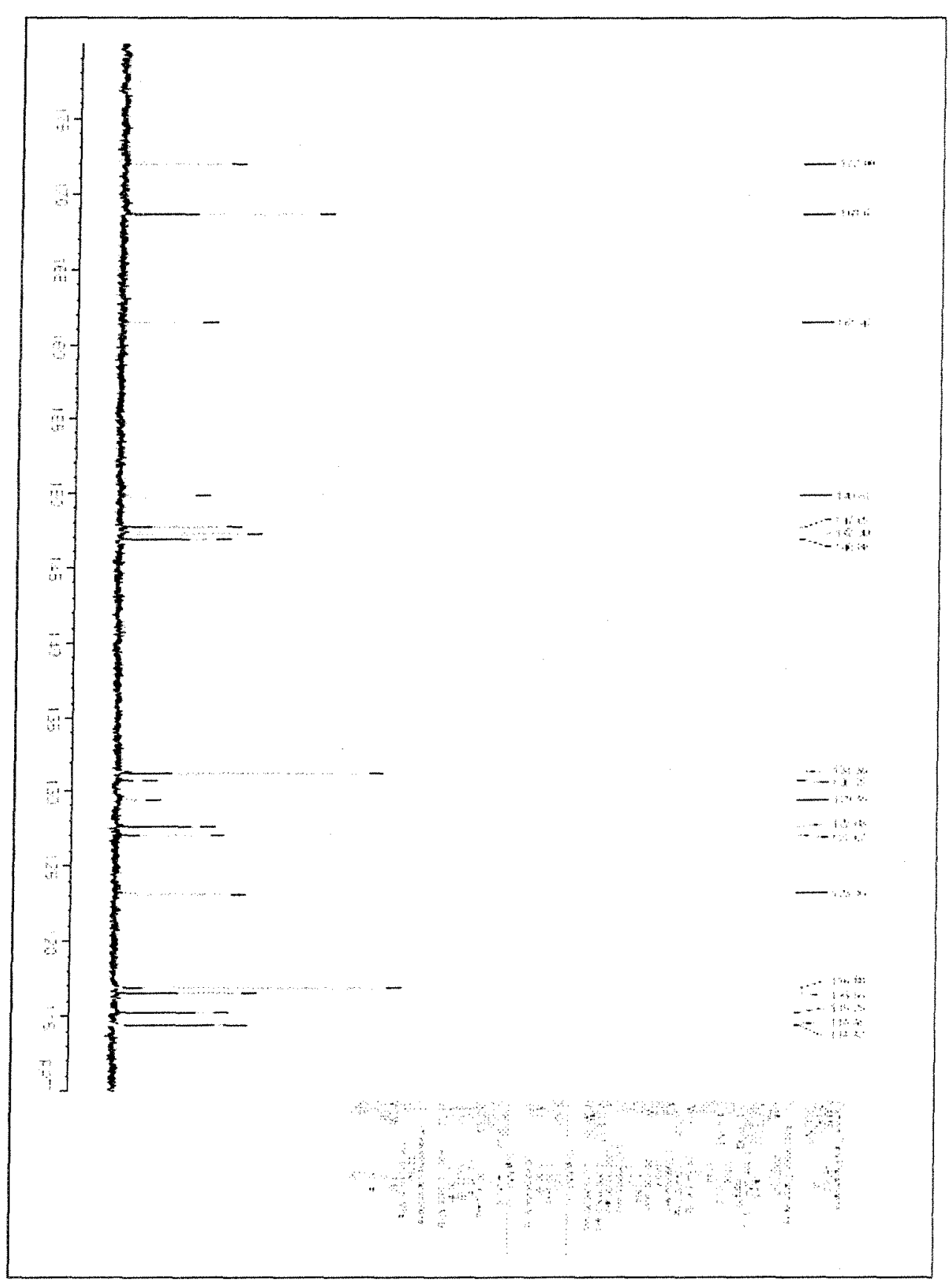


Deptl35 of compound (22)

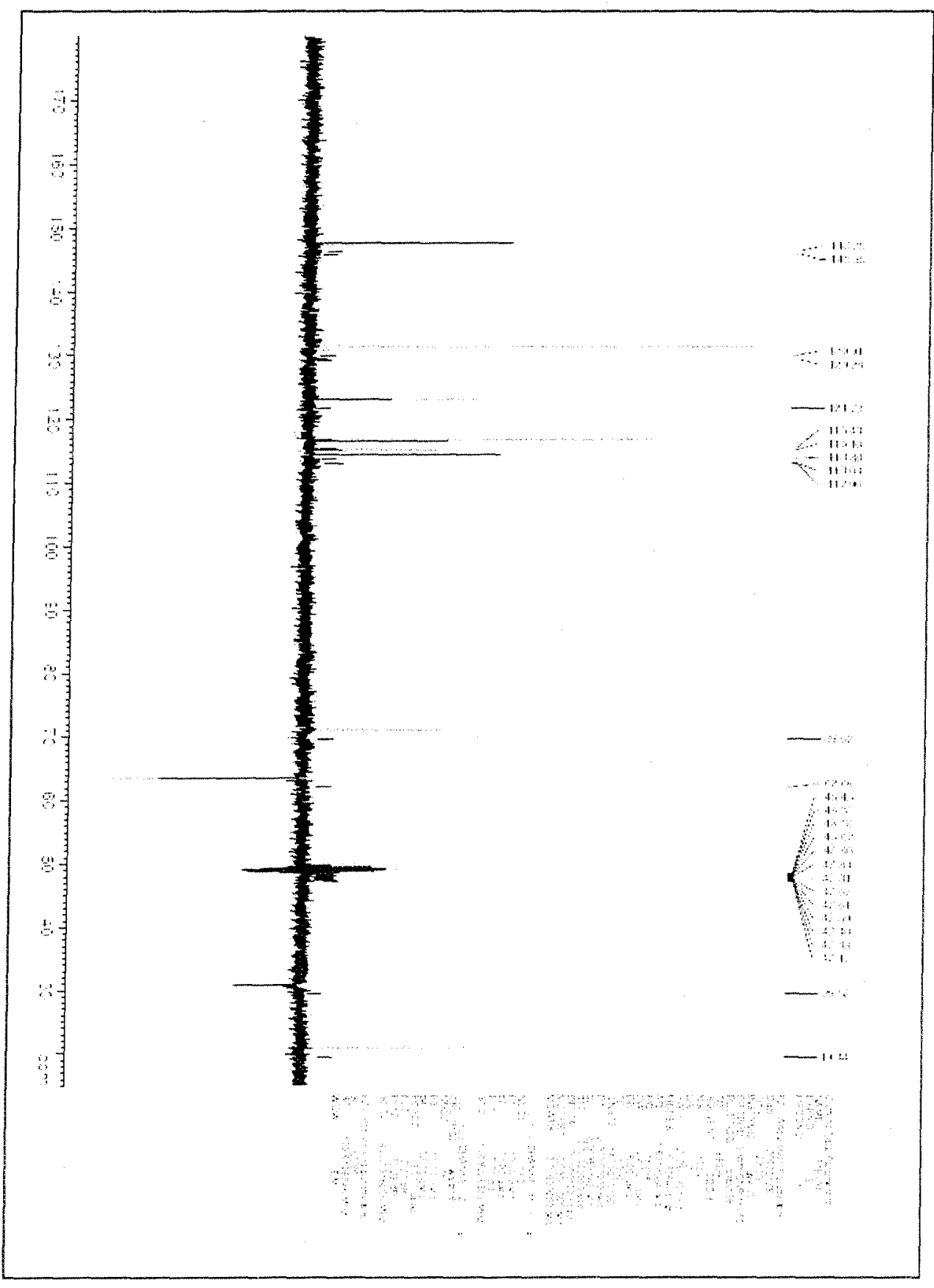


${ }^{1} \mathrm{H}$ of compound (23)

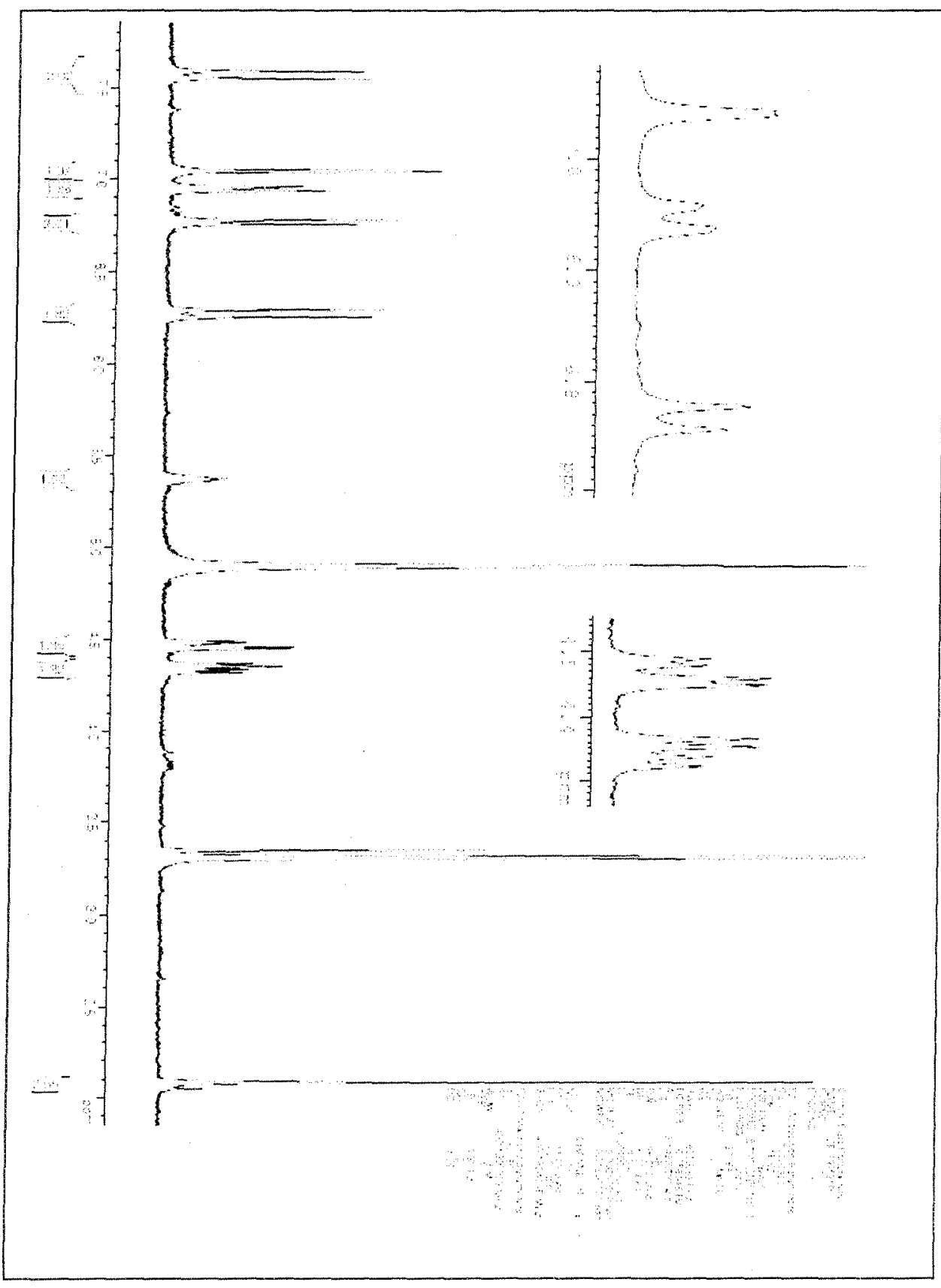




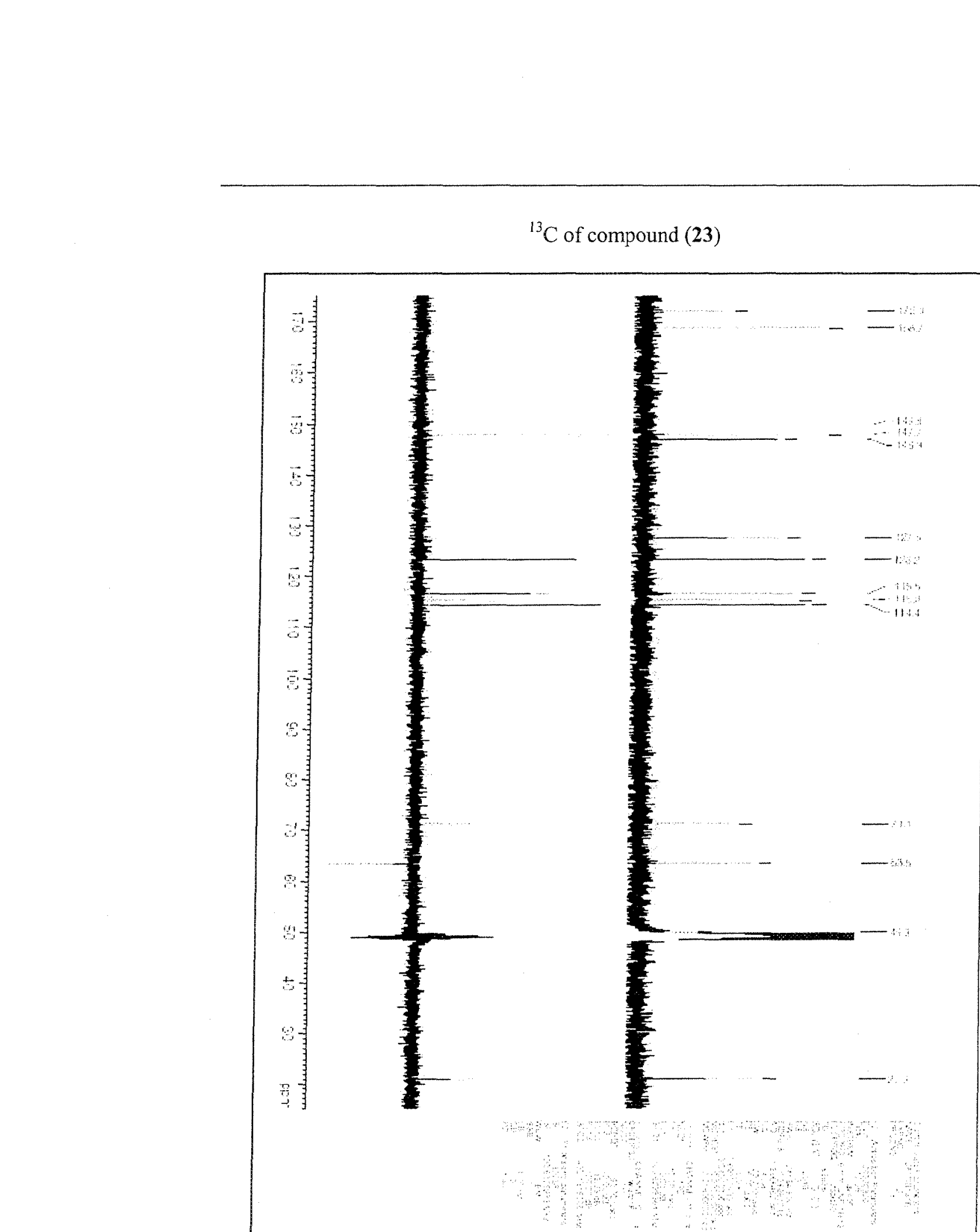


${ }^{1} \mathrm{H}$ of compound (24)

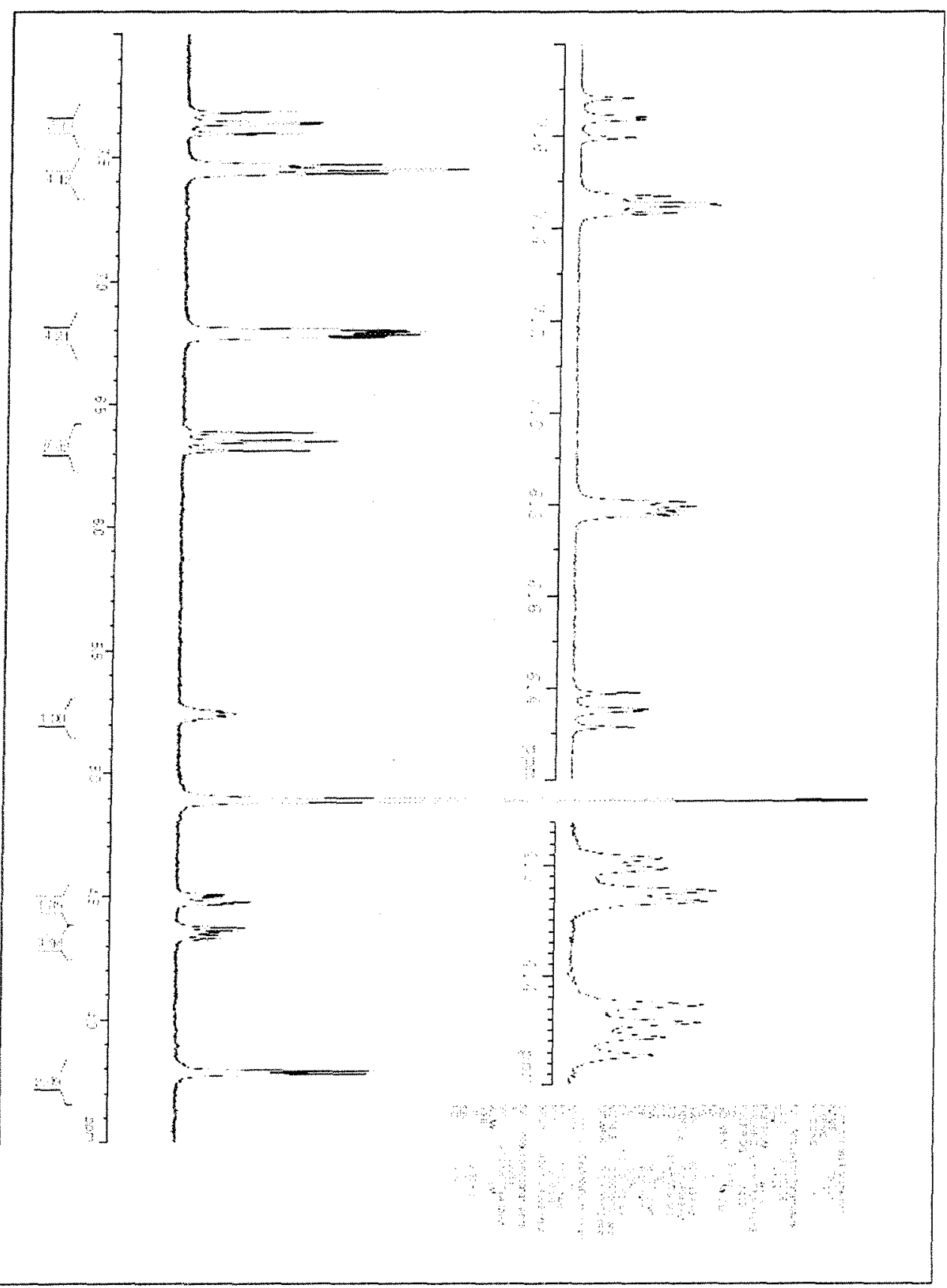


${ }^{13} \mathrm{C}$ of compound (24)

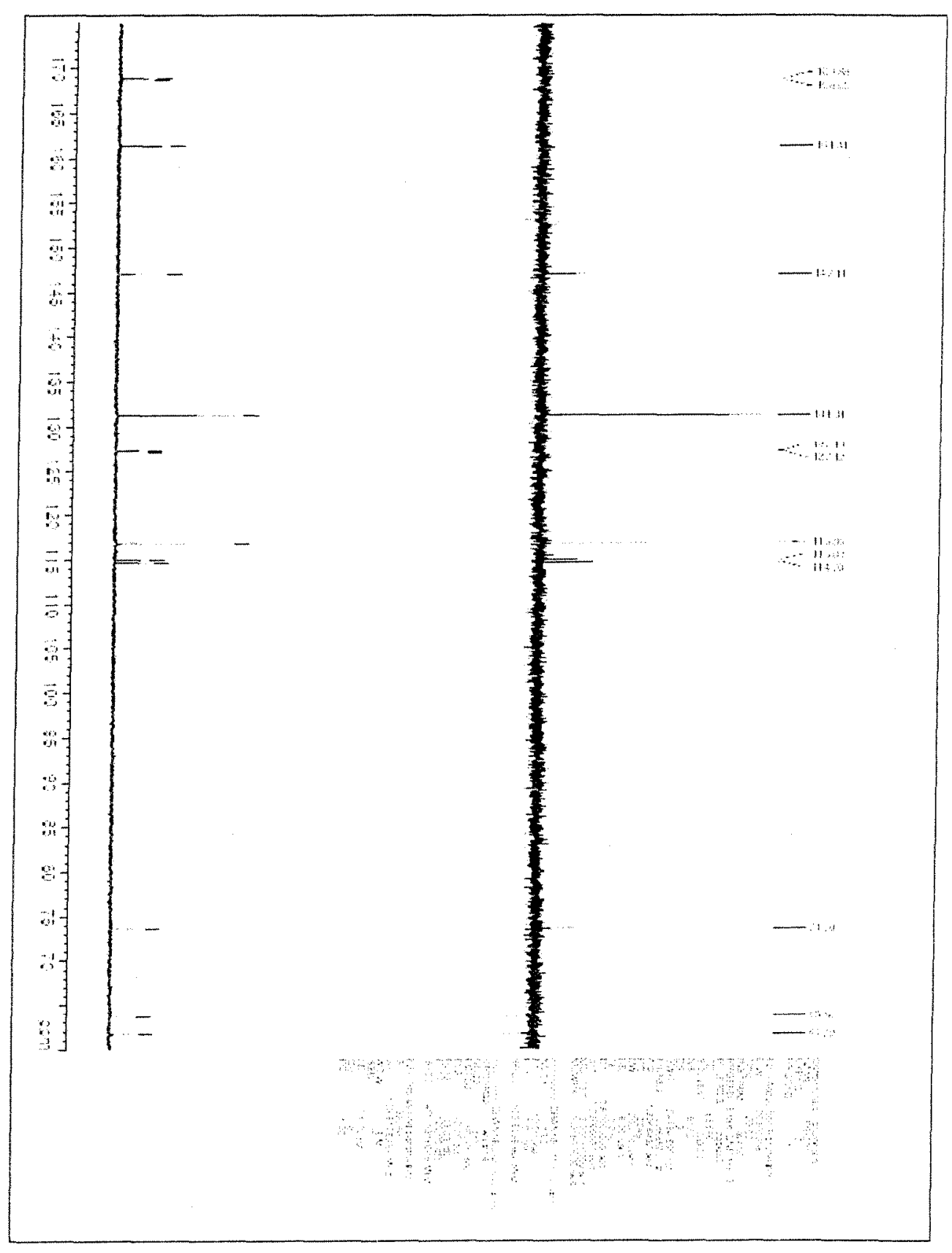

